\title{
Soils as a source of raw materials for ancient ceramic production in the Maya region of Mexico: Micromorphological insight
}

\author{
Héctor Víctor Cabadas-Báez, Sergey Sedov, Socorro del Pilar Jiménez-Álvarez, Daniel Leonard, \\ Becket Lailson-Tinoco, Roberto García-Moll ${ }^{\dagger}$, Iliana Isabel Ancona-Aragón, \\ María Lizeth Hernández-Velázquez
}

\begin{abstract}
Héctor Víctor Cabadas-Báez
hvcabadasb@uaemex.mx

Laboratorio de Geología, Facultad de Geografía, Universidad Autónoma del Estado de México. Cerro Coatepec s/n Ciudad Universitaria, Toluca, Estado de México 50110 , Mexico.
\end{abstract}

\section{Sergey Sedov}

Departamento de Edafología, Instituto de Geología, Universidad Nacional Autónoma de México 04510, Ciudad de México, Mexico.

\section{Socorro del Pilar Jiménez-Álvarez Iliana Isabel Ancona-Aragón \\ Facultad de Antropología, Universidad \\ Autónoma de Yucatán. Km. 1 Carretera Mérida \\ - Tizimín, Cholul, Mérida, Yucatán 97305, \\ Mexico.}

Daniel Leonard

HDR, 8690 Balboa Ave No. 200, San Diego,

California 92123, United States of America.

\section{Becket Lailson-Tinoco}

Facultad de Ciencias Sociales y Humanidades, Universidad Autónoma de San Luis Potosí, San Luis Potosí, Mexico.

\section{Roberto García-Moll}

Coordinación Nacional de Arqueología, Instituto Nacional de Antropología e Historia Córdoba 45, Col. Roma, Delegación Cuauhtémoc 06700, Ciudad de México, Mexico.

\section{María Lizeth Hernández-Velázquez} Escuela Nacional de Antropología e Historia. Periférico Sur y Zapote s/n. Colonia Isidro Fabela, Tlalpan, Isidro Fabela 14030, Ciudad de México, Mexico.

BOL. SOC. GEOL. MEX. 2018

VOL. 70 NO. 1

P. $21-48$

http://dx.doi.org/10.18268/BSGM2018v70nla2

Manuscript received: October 24, 2016. Corrected manuscript received: April 17, 2017. Manuscript accepted: August 31, 2017.

\begin{abstract}
Archaeological ceramics, like other technofossils, are such an important part of the record of pre-Hispanic human impacts in southern Mexico and Central America, that they provide a measure by which we can try to define the Early Anthropocene on the continent ( $c a .3000$ 1000 B.P.). This impact is also reflected in the use of raw materials for the manufacture of ceramic pastes. A review of the most common microscopic components of Maya ceramics (from Campeche, Chiapas, and Yucatán regions) was carried out, using the soil micromorphology fabric concept, which showed traits inherited from soils and sediments used as raw materials. Particular interest was given to: microstructure, groundmass, clay illuviation, redoximorphic features, organic remains, mineral weathering stages, and alteration features by burial context. Several of these components have been described before; however, the attention given to the interpretation of their origin and formation in natural context (prior to conversion into pottery) has been limited. The understanding of soil formation processes and their reliable microscopic evidence in an artifact can help to define ceramic production phases, including the circumstances for paste preparation, firing, and abandonment or disuse stages. At the same time, this microscopic evidence reflects the preferential selection of certain types of materials. Overall, the use of these resources is part of an ecological footprint related to questions of sustainability in Maya civilization.
\end{abstract}

Keywords: technofossil, Early Anthropocene, Maya ceramic petrography, soil micromorphology, soil formation processes.

\section{RESUMEN}

Las cerámicas arqueológicas, al igual que otros tecnofósiles, son parte importante del registro de impacto humano prehispánico en el sur de México y Centroamérica, proporcionando una medida en la cual podemos tratar de definir el Antropoceno temprano en el continente (ca. 3000 - 1000 A.P.). Este impacto se ve también reflejado en la utilización de las materias primas para la fabricación de las pastas cerámicas. Se realizó una revisión de los componentes microscópicos más comunes de la cerámica Maya (de regiones de Campeche, Chiapas y Tucatán), utilizando el concepto de fábrica de la micromorfología de suelos se evidencian rasgos heredados de suelos y sedimentos utilizados como materias primas. Se dio particular interés a: microestructura, masa basal, iluviación de arcilla, rasgos redoximórficos, restos orgánicos, fases de intemperismo de componentes minerales y rasgos de alteración por sepultamiento. Muchos de estos componentes han sido descritos antes, sin embargo, la atención que se les ha dado en cuanto a la interpretación de su origen y formación en su contexto natural (previo a su conversión en cerámica) ha sido poca. La comprensión de los procesos de formación del suelo y sus evidencias microscópicas relictas en un artefacto, pueden ayudar para definir las fases de producción cerámica, incluyendo el contexto de elaboración de la pasta, cocción y etapas de abandono o desuso. Al mismo tiempo, estas evidencias microscópicas, reflejan la selección preferencial de cierto tipo de materiales. En conjunto, el aprovechamiento de dichos recursos es parte de una huella ecológica relacionada a cuestiones de sustentabilidad en la civilización Maya.

Palabras clave: tecnofósil, Antropoceno temprano, petrografía de cerámica Maya, micromorfología de suelo, procesos de formación de suelo. 


\section{Introduction}

The chronological context of the Anthropocene as a geological epoch has stirred a wide debate among scientists. Particularly, the "Early Anthropocene Hypothesis" proposed by Ruddiman (2003, 2007) generates the need for a thorough search of the evidence of human impacts on the environment the invention of agriculture, as well as deforestation associated with it, increased levels of greenhouse gases, among others). Kennett and Beach (2013) and Beach et al. (2015) identified the "Mayacene" as a microcosm of the Early Anthropocene that appeared from $c a .3000$ to 10000 B.P. In their detailed review, Beach et al. (2015) integrated data for Maya impacts on climate, vegetation, hydrology, and the lithosphere from the analysis of lakes, floodplains, wetlands, and soils. They mentioned that the soils from the Maya region are potential stratigraphic markers, preserving evidence of a changing system (this includes soil enhancement and depletion, erosion and aggradation).

Soil registers the processes which influenced its natural development (bioturbation, clay accumulation, changes in aerobic-anaerobic conditions, and droughts). If soil is used as a raw material to sustain a civilization, including device manufacture, part of this memory (Targulian and Goryachkin, 2004) may reside in the artifacts. The artifacts can be used to date deposits of the Anthropocene epoch (Crutzen, 2002; Williams et al., 2014; Zalasiewicz et al., 2008, 2014a) and reflect cultural development. For authors such as Barnosky (2014), Ford et al. (2014), and Zalasiewicz et al. (2014a; 2014b), artifacts may be considered as ichnofossils and specifically as technofossils (Haff, 2014).

In ceramics, natural components amalgamate into anthropogenic lithologies (Zalasiewicz et al., 2014a; Williams et al., 2016; Hazen et al., 2017). In the Maya area, the mineralogy and organic components of ceramics preserve evidence of the firing technology (López-Varela, 2014) as well as of the raw materials used to produce the ceramics. The special mixture of raw materials known as fabric can reflect basic differences in the types and/or combination of ingredients that form the foundation of general ceramic categories classified by archaeologists (Whitbread, 1986, 1989, 2017; Howie, 2012). The description of ceramic fabric should be consistent among researchers in order to establish groups that are comprehensible and comparable between ceramic records (Albero-Santacreu, 2014).

Despite the long tradition of research in the Maya area (recorded mainly in technical reports for archaeology surveys, theses, and some scientific journals), petrography has been an underutilized technique (Howie, 2012; Bishop, 2014). Particularly relevant is the work of Jones (1986) because of its geographical and methodological scopes.

Soil micromorphology is an important tool for geoarchaeological studies associated with artifacts (e.g., Whitbread, 1986; Courty et al., 1989; Macphail et al., 1990; Goldberg and Berna, 2010; Walkington, 2010; Howard and Orlicki, 2016). Its primary objective is to interpret the composition and arrangement of microscopic constituents as evidence of the formation processes, whether natural or anthropic.

Experience interpreting soil evolution in the Maya region based on micromorphological studies (Sedov et al., 2008; Cabadas-Báez et al., 2010a, 2010b, 2017; Solleiro-Rebolledo et al., 2011; Solís-Castillo et al., 2013) has introduced the idea that part of the materials that comprise Maya ceramics are naturally occurring in the soils of the Yucatán Peninsula. These soils have been studied in terms of their genesis and classification since the mid-twentieth century (Quiñones, 1975; Isphording, 1978; Isphording and Wilson, 1974; Bautista et al., 2005, 2011).

The work presented here is based on comparative micromorphology of soil thin sections and ceramic fabrics from a diversity of sites in the Maya region of Mexico, in order to recognize the soil traces inherent in these artifacts. 


\section{Archaeological and environmental contexts}

The ceramic samples studied correspond to four areas within the Maya region in Mexico: (1) the upper Usumacinta region in the northeastern part of the state of Chiapas (Yaxchilán), (2) the southern part of Campeche (Cerro de Los Muertos, an inland site influenced by the presence of rivers and lagoons), (3) the northern coast of the state of Campeche (Jaina and Uaymil), and (4) the northern Yucatán Peninsula (Xcambó) (Figure 1). All samples derive from sherds recovered from a variety of structures and pits at the archaeological sites. The ceramics cover temporalities including Late Preclassic, Early Classic, Late Classic, and Postclassic periods.

The ceramic sherds from the southern and northern coast of Campeche, and from the northern Yucatán Peninsula, are housed at the Ceramic Laboratory in the Faculty of Anthropological Sciences of the Universidad Autónoma de Yucatán (UADY) in Mérida, Mexico. The ceramic sherds from Yaxchilán, Chiapas are part of diverse collections studied by Roberto García-Moll (Instituto Nacional de Antropología e Historia) over the course of several field seasons. Each sample was studied and classified by the Type-Variety system (Smith et al., 1960).

The best-studied samples in terms of their chronology were from the Yaxchilán area along the banks of the Río Usumacinta. Yaxchilán is located in the Lacandon Jungle in the state of Chiapas, Mexico, which borders Guatemala.

The site studied in the southern part of Campeche was Cerro de los Muertos, close to the Río Candelaria Basin, which was used for passage and communication between inland and coastal settlements during the Preclassic period. The ceramics from these sites present particularities in their surface finishes: red and brown bichrome with ribbed designs, fingerprints, and vessels with specific morphologies. They also share a common characteristic in the use of crushed ceramic or grog as a temper.
Jaina and Uaymil were ancient Maya maritime ports on the Campeche coast. These sites include Puuc style architecture and good quality ceramics generally referred to as pizarra. Jaina is a small island 42 ha in size located $40 \mathrm{~km}$ north of Campeche City and $70 \mathrm{~m}$ from the mainland. It is an artificial island built by the Maya with several tons of sascab (calcarenite extracted from the Pleistocene-Holocene materials of the littoral beach ridge); it is the largest island ever built in the ancient Maya world. Uaymil is located $25 \mathrm{~km}$ north-northeast of Jaina and $2.5 \mathrm{~km}$ inland from the coast. Cobos (2005) suggested the function of the site was a trans-shipment station facilitating the movement of goods to Chichen Itza and Uxmal. Xcambó, on the northern coast of the state of Yucatán, lies in a swamp with diverse ecological resources available for use by the ancient Maya. It was a commercial port that managed marine resources starting in the Early Classic (200 - 600 A.D.), when it was probably an important site controlled by Izamal. Analysis of Xcambó ceramics (Jiménez-Alvarez, 2002; Jiménez-Álvarez et al., 2000, 2006) has suggested interaction with sites from wide-ranging areas including south-central Veracruz, the Grijalva Basin, the Usumacinta Basin, and Guatemala, among others (Sierra-Sosa, 2004).

The soils we used for comparison with the ceramic pastes came from an area representing some of the best pedogenic evolution in the Maya region: the northern and southern Yucatán Peninsula (and the Luvisols found there) (Figure 1). Luvisols are identified by the evidence of clay migration in the lower part of soil profiles, generating the argic horizon (IUSS Working Group WRB, 2015). Particularly interesting is the abundance of fine clayey material (enriched in kaolinite), and the pigmentation with iron oxides (from pedogenic origin) observed at both macro- and micromorphological scales. These soils were studied in detail by Cabadas-Báez et al. (2010b) in the localities of Kantunilkin (state of Quintana Roo), Bolonchen (state of Campeche), and Carrillo Puerto (state of Quintana Roo). The soils were selected for their mi- 


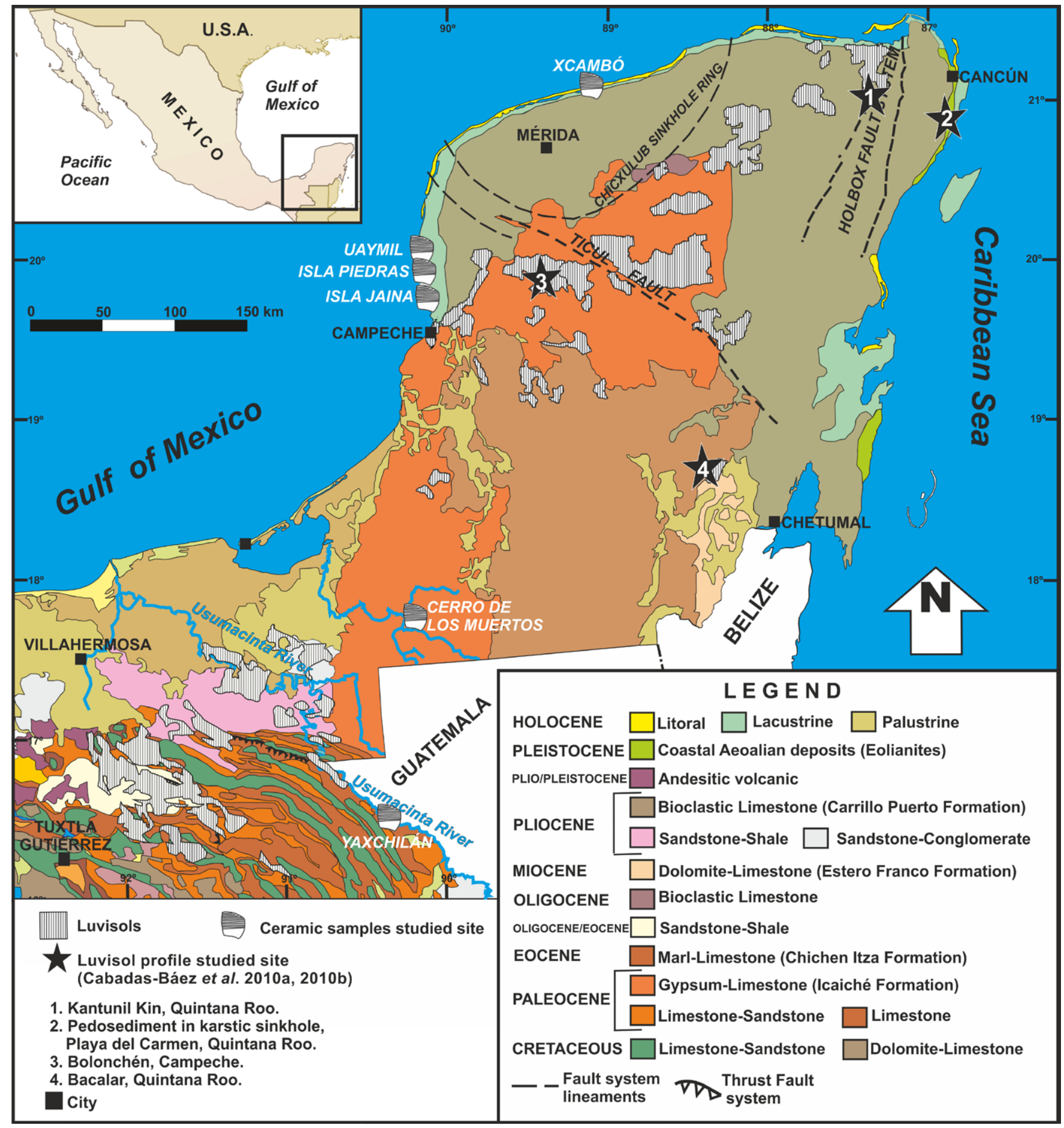

Figure 1 Site location samples of soils and ceramics in the geological context of the Yucatán Peninsula. (Compiled from Bautista et al., 2005; Servicio Geológico Mexicano, 2007; Cabadas-Báez et al., 2010a, 2010b; Solleiro-Rebolledo et al., 2015). 
cromorphological similarities to Maya ceramics, specifically between the b-fabric of the soil argic horizons and the clay matrix of the ceramic.

\section{Materials and methods}

The preparation of ceramic thin sections is similar to that suggested by soil micromorphology manuals (Bullock et al., 1985; Stoops, 2003). The samples were completely impregnated with epoxy resin (with a refractive index of 1.54 , similar to quartz), in order to preserve important details, including the slip (a liquid mixture of clay and other fine materials suspended in water to decorate the surface of the ceramic material).

Microscopic descriptions follow Bullock et al. (1985) and Stoops (2003). In particular, this work follows the system of Whitbread (1986, 1989, 1995), which combines elements of standard descriptive methods used in sedimentary petrography with techniques from soil micromorphology.

Observations were made using an Olympus model BX51 petrographic microscope and recorded using Image-Pro Plus v. 5.1.1 software. In addition, certain samples were photographed using an Epson Scanner Perfection V600 at 6000 dpi in order to obtain a general overview. A total of 32 ceramic samples were observed and compared with 24 samples of argic horizons from soil profiles. A semi-quantification of the coarse/fine materials ratio was described with visual diagrams for use in petrography (Castro-Dorado, 1989).

\section{Results and discussion}

\subsection{SOIL GROUNDMASS, GLAY ILLUVIATION RELICTS, AND GLAY TEMPER}

One of the less-described features in Maya ceramic petrography is the "heterogeneity" of fine components present in the ceramic matrix. Parts of these components were considered in the methodology proposed by Whitbread (1986), where the existence of mixed matrices in the same paste is evidence of a clay-tempered ceramic (inclusions of unfired clay which were introduced into the paste by the potter, Whitbread, 1986; Velde and Druc, 1999). Poor wedging of a mixture of clays may leave traces of textural and color variation in the matrix paste (Whitbread, 1986).

The artificial heterogeneity created by mixing two or more clay sources in a wet plastic state produces features with irregular shapes and sometimes diffuse boundaries (Whitbread, 1986; Quinn, 2013), but the optical behavior of each "individual block" may denote a different origin. These aspects may imply the incorporation of argic, including luvic, horizons into the ceramic paste (Figure 2a, b, c, d). The presence of soil groundmass "blocks" under crossed polarizers may be due to an "immature state" in the paste arrangement (Krishnan and Shah, 2005; Maritan et al., 2005). The possibility exists that the fine fraction of the ceramic may have been collected from surficial clay soil horizons, where organic matter generally accumulates; in ceramics such as those from Cerro de los Muertos, Campeche (Figure 2g), some relicts of typical A horizons were distinguishable as clay temper with granular microstructure (Figure 2h).

Luvic horizons characterized by clay illuviation are observable in the form of "blocks" inside Tinaja Red ceramic paste from Yaxchilán, Chiapas (Figure 2a, b). In a Luvisol, the illuviation produces clay coatings by the movement of those particles in an aqueous mediwhich gravity transfers from the higher soil horizons to the lower ones (Figure 2c, d). Sometimes, these coatings exhibit a typical configuration of microlamination infillings, which are hosted in porous regions. The optical behavior of the natural clay coatings presents extinction bands under crossed polarizers that extend through the microlaminated regions, and is independent of the optical response in the ceramic matrix. The presence of reworked clay coatings is common where well-oriented clay is clearly visible, evidenced by birefringence and band extinction (Figure 2e, f). The fragmentation of the clay coatings is likely produced by the ceramic paste preparation. 
The clay illuviation over carbonates is another phenomenon described at the boundary between the soil profile and the underlying limestone (Bronger and Sedov, 2003; Merino and Banerjee, 2008; Cabadas-Báez et al., 2010b). Similar features were observed in Cerro de Los Muertos ceramics from Campeche (Figure 2i, j). Figures 2k and 2l show the phenomenon at the transition between a luvic horizon and the underlying limestone from Kantunilkin, Quintana Roo. Part of the added temper could have been taken from the lower soil horizons with influence from the carbonate parent material. Similar observations were reported by Gillot (2014) in Maya mortars from Río Bec, Campeche, with the presence of "argillaceous grains" (that include carbonate in their structure).

\subsection{INHERITED REDOXIMORPHIC FEATURES FROM} SOIL

The Fe-Mn nodules or concretions have been described as components of the ceramic temper, without much attention to the fact that these features may generate naturally in the soil. Nodules in soil materials have been described in the field since the early days of soil science and were without doubt the first features to be recognized in thin sections of soil (Kubiëna, 1938). In the illuvial horizons from soils of Bolonchen, Campeche, it is common to find typical concentric and nucleic Fe nodules (Bullock et al., 1985; Delvigne, 1998; Stoops, 2003; Quinn, 2013) (Figure 3d, f) that are visible as mineral components in the ceramic. The microconcentric structure (Figure 3d, e, f) present
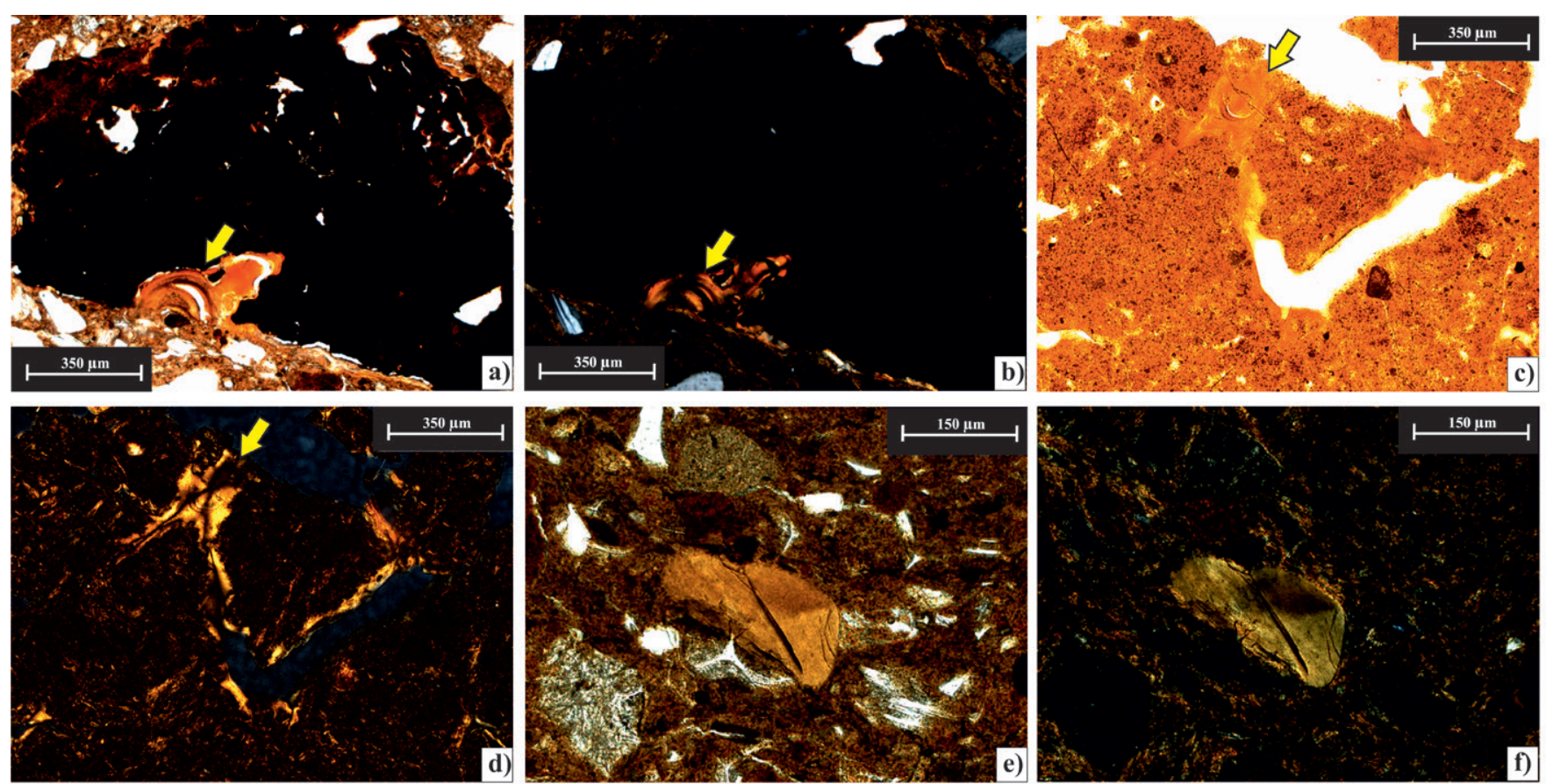

Figure 2 Soil groundmass, clay illuviation relicts, and clay temper.

(a, b) Floating soil groundmass relict in the Tinaja Red ceramic from Yaxchilán, Chiapas. (a) The distinctive feature is clay illuviation in the lower part of the dark red "block". (b) in cross-polarized light (XPL) where microlaminations with extinction bands are visible. (c, d) Clay illuviation in Bt horizon (Chromic Luvisol) from Kantunil Kin, Quintana Roo. (c) With plane-polarized light (PPL), clay illuviation is evident in the limpidity (Stoops, 2003) of the soil groundmass marked with the arrow. (d) With XPL the same area displays extinction bands.

(e, f) Reworked clay coating in Nimún Brown ceramic, Nimún group, from Jaina, Campeche. (e) PPL. Rounded clay coating fragment, yellowish-brown color suggests the presence of iron oxide and hydroxide components. (f) XPL. Well-oriented clay with extinction bands proposed a clay illuviation origin and consequent fragmentation.

Continued on the next page. 

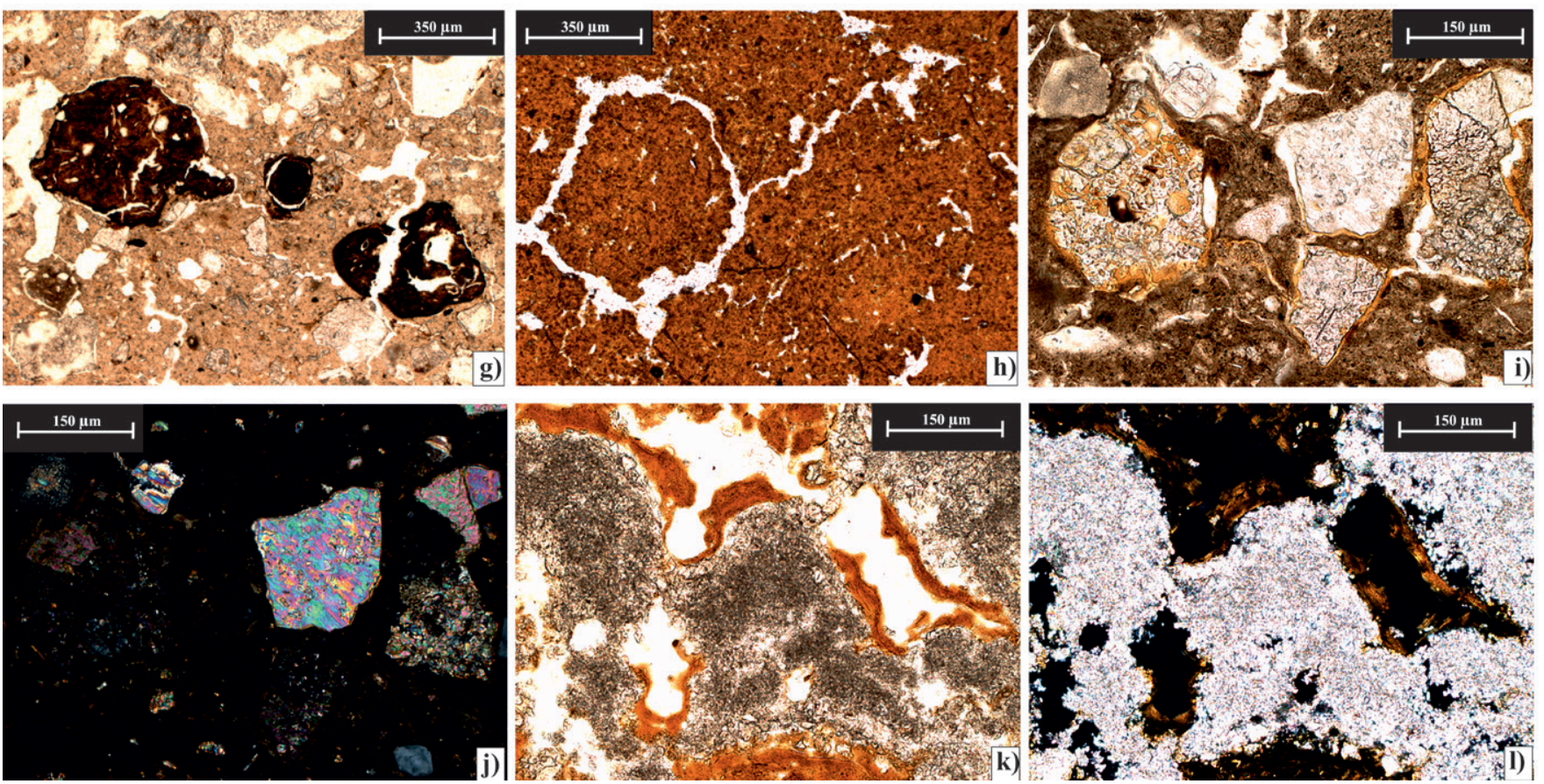

Figure 2 (Continuation) Soil groundmass, clay illuviation relicts, and clay temper.

(g) PPL. Subrounded fragments of apparent dark-brown soil-relict groundmass in ceramic sample from Cerro de los Muertos,

Campeche. The dominance of fine fractions in the dark blocks is evident, as well as the tendency to conserve traces of granular structure (as relicts of fine organic matter).

(h) PPL. Relict rounded blocky microstructure in a Bt horizon, Chromic Luvisol soil, from Bacalar, Quintana Roo. Note the reddishbrown color of the groundmass from fine organic matter. The Bt horizon is rich in clay, and the presence of rounded blocky structures and organic matter impregnations denotes the evolution from an A horizon. The clay horizons of the soil selected to form the ceramic clay matrix are not homogeneous and contain relict structures.

(i, j) Rounded and subrounded carbonate particles with apparent clay illuviation in ceramic, Cerro de los Muertos, Campeche. (i) PPL. Sparite fragments with high relief and yellowish clay coatings inside and around the carbonate particles. (j) XPL. High birefringence denotes the presence of carbonates. Clay coatings show low birefringence. The tendency towards isotropy in the clay coatings is an important aspect, whether it's a natural feature in the carbonate raw material, or produced during the ceramic manufacture (as part of the grog or recycled mortars).

$(k, I)$ Clay coatings on carbonates in BtC horizon, Chromic Luvisol, Kantunil Kin, Quintana Roo. (k) PPL. Carbonates (micrite) have the highest relief and typical gray colors. The yellowish clay coatings are microlaminations in pores. (I) XPL. Clay coatings have lower interference color and typical band extinction.

in the nodules is the product of alternating redox conditions in the soil, although it may also have been inherited from the dissolution of the underlying rock (Cabadas-Báez et al., 2010b). Iceland and Goldberg (1999) reported the presence of Fe concretions in the ceramics from northern Belize, where the access to Luvisols and Gleysols with redoximorphic features must have been relatively easy.

Similar features to Fe-Mn nodules or concretions, which can cause some confusion, were reported by Chung (2009) and Loya-González and Stanton
(2014) as lumps or granules of iron. These components were described as clay particles containing iron oxides and hydroxides, with sub-rounded to rounded spherical shapes. For some authors (Whitbread, 1986; Quinn, 2013) these clay pellets or "clay lumps" were "lithic weathered fragments" (Chung and Song, 2014). For Whitbread (1986), the clay pellets can be characterized by merging boundaries, a high degree of roundness, equant shape, and poor internal orientation (Figure 3a, b). From our perspective, part of these "pellets" could be soil fragments used as clay-temper, which have 

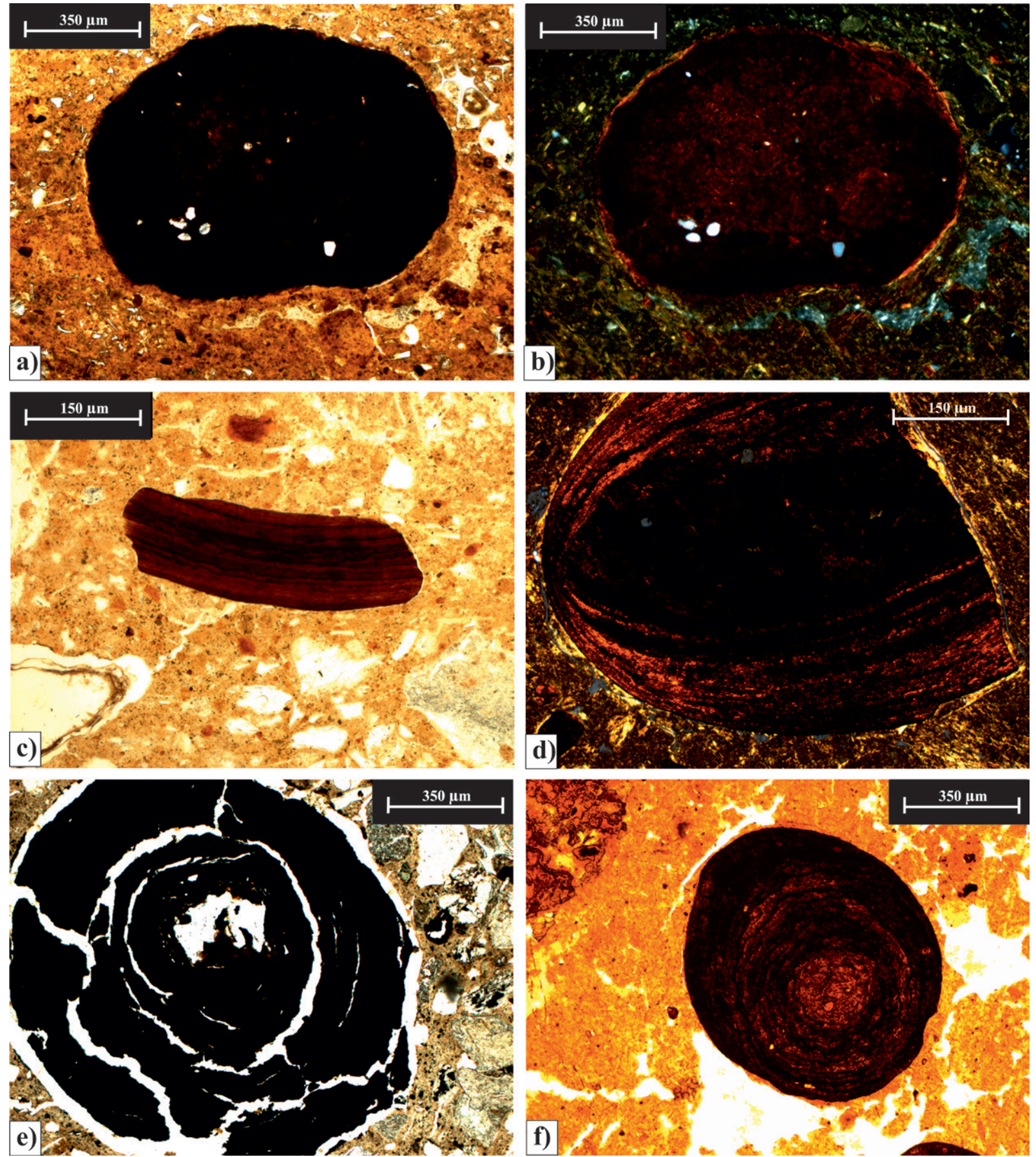

Figure 3 Inherited Fe-Mn redoximorphic features.

(a, b) Typical nodule (Stoops, 2003) in Baca Red ceramic (Ceramic Group Baca) from Uaymil, Campeche. (a) Plane-polarized light (PPL).

(b) Cross-polarized light (XPL). The red colors are associated with Fe composition and the granostriated b-fabric (birefringence rim around the nodule by the clay domains).

(c) PPL. Reworked fragment of concentric nodule (Stoops, 2003) in Baca Red ceramic (Ceramic Baca Group, Uaymil, Campeche). The curved morphology and microlaminations denotes the nodular origin of this Fe feature.

(d) XPL. Concentric nodule (Stoops, 2003) in Bt horizon (Chromic Luvisol, Bolochén, Campeche). With XPL, the granostriated b-fabric halo and the vertic properties in the groundmass are more evident (dominated by strial fabric).

(e) PPL. Concentric nodule (Stoops, 2003) in Tres Naciones Gray ceramic (Yaxchilán, Chiapas). The dark black color suggests the presence of Mn, even organic matter. Delvigne (1998) and Quinn (2013) use the term pedogenic nodule or pisolith for this feature. (f) PPL. Concentric nodule (Stoops, 2003) in Bt horizon (Chromic Luvisol) from Bolochén, Campeche. 
been reworked during the paste preparation to be incorporated into the ceramic matrix (Figure 3c).

\subsection{THE MICA GROUP MINERALS}

The mica group minerals have received some attention in petrographic studies of Maya ceramics, however, they have not been sufficiently explored. Their planar nature enables them to float, causing them to accumulate in areas of deposition with much finer material. Mica crystals in sand-size fractions may be susceptible to compaction effects during natural sedimentation (Tucker, 2012) and throughout preparation and modeling of paste (Velde and Druc, 1999), which can generate exfoliation.

In different reports across the Maya region, mica minerals have commonly been described as temper in ceramics. In such reports, confusion between muscovite and biotite, and even chlorite, is common. Some authors (Chung, 2009; Obando et al., 2011) have inferred the presence of muscovite based on the presence of white color mica (in plane polarized light); however, there is the possibility that the interference colors do not match those in the muscovite (which are higher than the third order birefringence in the Michel-Levy chart: $0.036-0.049)$.

In accordance with the optical properties, we suggest that most of the micas described in Maya ceramics are in transition to clay minerals with an intermediate to advanced weathering stage. This was described by Delvigne (1998) as "pellicular patterns," producing the first order interference colors under crossed polarizers (Figure 4c, d). Bautista et al. (2005) and Cabadas-Báez et al. (2010a; 2010b) studied weathering in soils systems from southern Mexico; they described mineral phases integrated with interlayered phyllosilicates.

Authors, including Shepard (1964) and Reedy (2008), have already proposed that the micas present in abundant proportions in the ceramic are part of the "non-plastic natural inclusions" that contain clay needed to prepare the paste. According to the observations of samples of pedosediments from Playa del Carmen, Quintana Roo (Figure 4a, b), micas that may be included as sand or silt fraction in the ceramic paste. Part of those micas (Figure 4a) may be found in volcanic materials. In other cases, the small crystal size made it necessary to describe with detail the soil groundmass, where some mica flakes are visible under crossed polarizers; the low interference colors denote weathering stage or tendency to form interlayered phyllosilicate minerals (Figure 4b). In ceramics from Yaxchilán it is interesting to observe several degrees of weathering in the mica minerals, even in the same pottery samples (Figure 4g, h, i, j).

Mica minerals are a kind of tracer in Maya ceramics, particularly in the Usumacinta region and in Central America (Bishop, 1994; Obando et al., 2011) with the nearby plutonic-metamorphic complexes (Ortega-Gutiérrez et al., 2007) (see Figure 1). In some cases, micas could be associated with the influence of El Chichón volcano tephras (Tankersley et al., 2011) (Figure 4e, f). However, the mineralogical and geochemical comparisons are not definitive. The high biotite content in the Yaxchilán ceramics could be associated with a nearby tributary of the Usumacinta, which brought allochthonous mica from its local catchment.

Mica may be confused with vegetable tissues (something common, even in the soils, where in some descriptions [e.g., Heraud, 1996] they are denoted as mica-schist relicts). This confusion is based on the weathering morphology, related to cleaves readily into thin sheets. In some cases, it is possible to distinguish low interference colors, especially towards the peripheral regions of the crystals. In the cases in which it is not possible to observe the interference colors, the most probable alternative is the identification of partially degraded or burnt plant tissue (Canti, 2017; Ismail-Meyer, 2017). Another clear difference is the scale of the mica and vegetable tissues: the vegetable tissues are usually larger $(>300 \mu \mathrm{m})$ than mica crystals (Figure 4k, l). 


\subsection{PARTIGULARITIES OF VOLGANIC GLASS}

The presence of volcanic glass in Maya ceramics has been widely discussed (since the pioneering work of Shepard [1937]) in light of the absence of igneous outcrops in the Maya region, principally in the Lowlands of the Yucatán Peninsula. Several authors suggested a source of volcanic ash distributed in different regions (Shepard, 1964, 1968; Arnold, 1985; Ford and Glicken, 1987; Ford and Rose, 1995; Ford and Spera, 2007) that was completely used up by the ancient Maya.

A variant of this model advocates soil formation processes, which implies that volcanic materials have been weathered (Isphording, 1974; Isphord- ing and Wilson, 1974; de Pablo, 1996; Tankersley et al., 2011; Milawski, 2013). Following this idea, some ceramics from Yucatán and Chiapas show volcanic glass in sand-sized pumice particles with apparent clay coatings and infillings inside vesicles, generating an amygdaloidal texture (Figure 5). The characteristic aspect of these infillings is the optical anisotropy, which creates uncertainty about the origin of this feature and its relation with weathering processes in the volcanic glass. The general idea is about the devitrification (particularly with the formation of palagonite) (Villaseñor and Graham, 2010). However, this alteration is associated with basaltic rocks (Marshall, 1961), and it is petrogenetically incompatible with the magmatism from
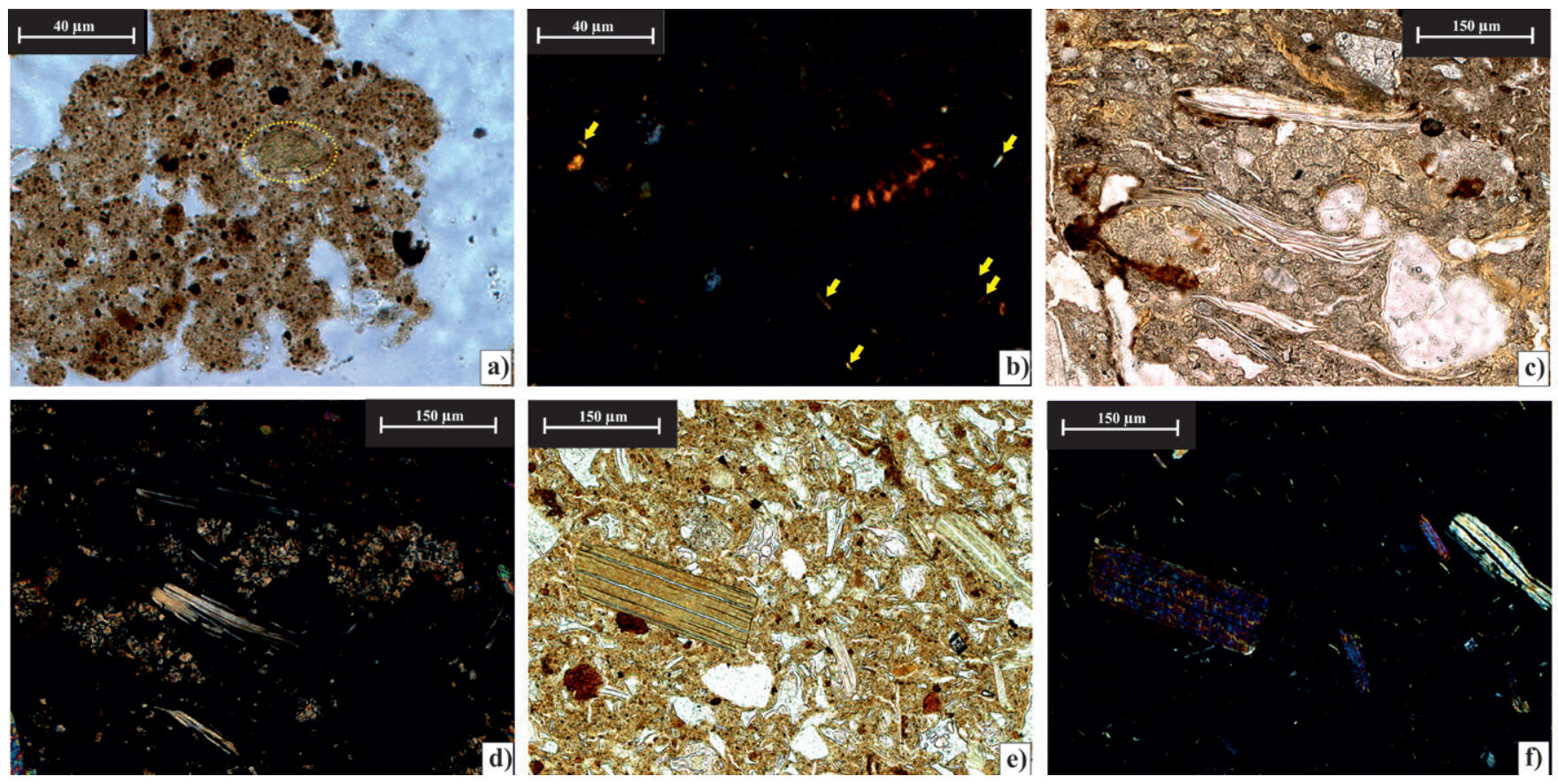

Figure 4 Mica group minerals particularities.

(a) Plane-polarized light (PPL). Mica crystal (basal section) in soil groundmass (pedosediment, described as soil A horizon) from Playa del Carmen, Quintana Roo,. The unaltered crystal has a pale-green color.

(b) Cross-polarized light (XPL). Small mica "flakes" (marked with yellow arrow) dispersed in the soil groundmass (pedosediment, described as soil A horizon) from Playa del Carmen, Quintana Roo,. The low interference color denotes the transition to interlayered phyllosilicates, including weathering processes.

(c, d) Mica crystals in ceramic, Cerro de Los Muertos, Campeche. (c) PPL. Cleavage in one plane is evident where the crystal is altered and "open" (phylloporos as described by Delvigne, 1998) with a residual fibrous habit. (d) XPL. The mica is clear with low interference color. The rest of the interference colors denote the presence of carbonates.

(e, f) Biotite crystals as temper in Lucha Incised ceramic from Yaxchilán, Chiapas. (e) PPL. The typical brownish-green color of biotite crystal with cleavage into thin sheets. (f) XPL. ( g), The high interference color in the biotite crystal demonstrate its reduced weathering stage. Some brown mica crystals have low interference color, associated with transition to clay minerals.

Continued on the next page. 

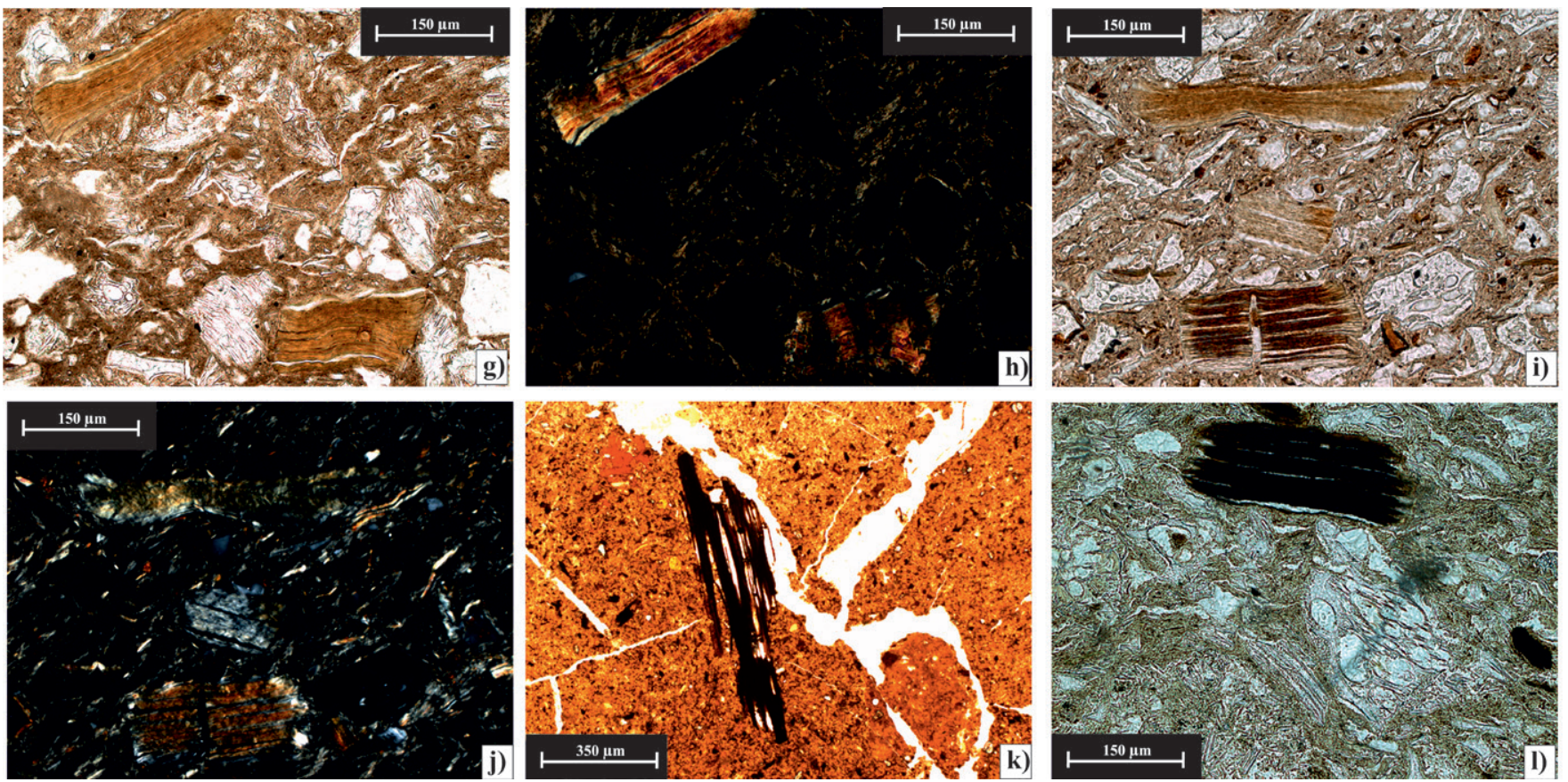

Figure 4 (Continuation) Mica group minerals particularities.

$(\mathrm{g}, \mathrm{h})$ Moderately weathered biotite crystals in Infierno Black ceramic from Yaxchilán, Chiapas. (g) PPL. Biotite crystals with partially wavy structure produced by volume increase. (h) XPL. It is still possible to observe high interference color in the center of the crystals, but the low interference color dominate from the possible transformation to clay minerals.

(i, j) Advanced weathering in mica crystals from Silk Grass ceramic (Sotero Red-Brown Group) from Yaxchilán, Chiapas. (i) PPL. It is interesting to observe the coexistence of different weathering degrees in the mica crystals, evidenced by colors and morphology of the interlayered pores. (j) XPL. The red color in the mica could be related to iron content by minute crystals of goethite distributed parallel to the cleavage planes (Delvigne 1998).

(k) PPL. Plant tissue (charcoal) with a morphology similar to mica minerals, A horizon soil Chromic Luvisol, Kantunil Kin, Quintana Roo. The most evident difference with the mica crystals is the size of the structure, and the presence of cellular arrangement "interlayered in the cleavage plane."

(I) PPL. Weathered mica crystal (intermediate-high alteration) from Chaquiste printed ceramic, Yaxchilán, Chiapas. Opaque minerals appear black in PPL. Cleavage planes in mica are visible, as well as volume increases from weathering. The dark color and lateral edges simulate the appearance of plant tissue.

Central America or southern Mexico, which is more associated with rhyolitic compositions (Carr and Stoiber, 1990; Rose et al., 1999).

The presence of clay coatings is contradictory to the dominant recognition of fresh volcanic glass temper in Maya ceramic petrography (Ford and Rose, 1995; Ford and Spera, 2007; Ford et al., 2017); just a few reports describe weathering details of volcanic glass (Bishop et al., 2005; Chung and Song, 2014; Obando and Jiménez, 2016). Coatings and infillings evidencing illuviation of fine colloidal materials are relatively common in volcanic soils (Andosols) derived from humid tropical regions (Jongmans et al., 1994; Sedov et al.,
2003). The soils near El Chichón volcano possess some of these characteristics (Solleiro-Rebolledo et al., 2007).

The coatings and infillings could be considered the product of in situ co-precipitation of $\mathrm{Al}$ and $\mathrm{Si}$, forming allophane. They are subsequently transformed by desillication in imogolite and later to very fine-grained gibbsite, giving the coatings an anisotropic aspect under crossed polarizers (Sedov et al., 2010); this hints at aspects warranting more in-depth study, for example the age of the volcanic deposits. Recently, reworked volcaniclastic deposits in the Usumacinta River have come to be considered an important raw material source 

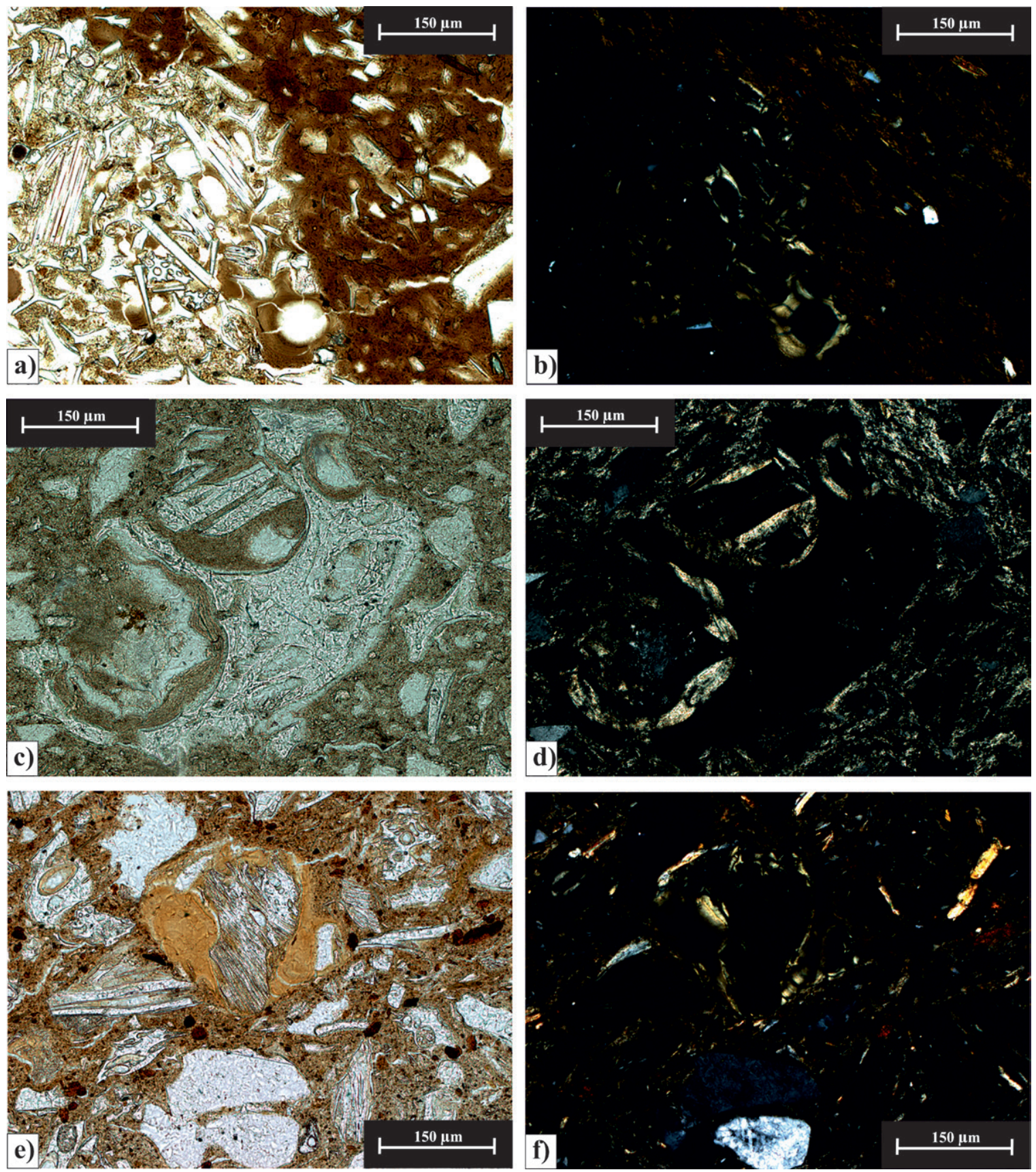

Figure 5 Particularities of volcanic glass.

(a, b) Pyroclastic rock fragment with amygdaloidal texture (clay coatings inside) in Chavihau Red Specular ceramic (Baca Group) from Xcambó, Yucatán. (a) Plane-polarized light (PPL). Volcanic glass shards compressed in contrast with the ceramic matrix. (b) Crosspolarized light (XPL). The most distinctive feature is the birefringence from coatings inside the pore walls with a pale-yellowish color (optical behavior as a single crystal rim of well-oriented clay) and the ceramic matrix with less birefringence in pale-reddish color.

The volcanic glass is isotropic.

(c, d) Pumice fragment with amygdaloidal texture (clay coatings) in Lucha Incised ceramic from Yaxchilán, Chiapas. (c) PPL. Volcanic glass shards and partially fragmented, coarse pumice infilled with brownish clay material are evident by high optical relief. (d) XPL. The infillings display the highest birefringence, contrasting with the striated fabric of the ceramic clay matrix. The relatively thick microlaminar structures suggest accumulation in the volcanic glass vesicles.

(e, f) Pumice fragment with fluidal texture surrounded by limpid clay material in Lucha incised ceramic from Yaxchilán, Chiapas. (e) PPL. Contrast between the yellowish clay color and the brownish color of the clay matrix is evident. (f) XPL. The limpid clay displays anisotropy, with a rim of well-oriented clay in low interference color. The volcanic glass is isotropic. 
for volcanic glass temper, associated with ancient hidromagmatic eruptions (Cabadas-Báez et al., 2017). The replacement of glass shards by clay minerals is a common feature of volcanoclastic sediments (Leggo et al., 2001), a vein little explored by Maya ceramic petrographers.

\subsection{THE GARBONATES: QUESTIONING DIVERSITY}

The carbonate fabric is the most abundant feature observed in Maya ceramics; part of its origin is related to the environmental context: the karstic landscape. The majority of Maya petrography studies describe the differences in carbonate morphology (Jones, 1986) based on classical sedimentary classifications. Micrite and sparite sizes and their concentrations are the typical characteristic described in the ceramic pastes; however, explanations about their origin and crystallization stability are rare. According to Casadio et al. (1991) and Velde and Druc (1999), the utility of this temper comes from its resistance to cooking heat; the alteration processes in the ceramic could particularly imprint carbonate morphologies, generating uncertainty in the interpretations (Buxeda i Garrigós and Cau-Ontiveros, 1995).

In certain ceramics, such as those from the site of Jaina in Campeche (Figure 6a), it was easy to identify primary carbonate material due to the presence of marine organism remains (bioclasts). These structures are found not only in ancient limestones, but also in beach sediments and ridges in the Yucatán Peninsula (Aguayo et al., 1980; Ward, 1985), where potters could have collected them as temper. The correct description and interpretation of several carbonate facies components (Fabbri et al., 2014) must be an essential constituent of provenance studies (Quinn and Day, 2007), something still neglected in Maya ceramic petrography.

In Chabihau Specular ceramics from Jaina, Campeche (Figure 6c, d), it is possible to find carbonate materials with a different configuration than primary carbonates (Figure 6a) suggesting carbonate generation in a terrestrial environment. These laminar materials are known as caliche or calcrete, and are distinct because they are carbonates generated during platform exposure to land. They accumulate as a result of the carbonate evaporation-precipitation phenomena produced by the tropical climate (a net annual moisture deficit in the soil is necessary), which includes the processes of dissolution and recrystallization phases (other critical factors are the topography, vegetation, action of microorganisms, and even dust accretion by storms) (Flügel, 2010). The caliche is on the surface of most sedimentary sequences from the Yucatán Peninsula, underlying the soil; its fragmentation was likely another source for temper production. Micritic and sparitic phases are dominant in the caliche microstructure; if this microstructure is fragmented it is difficult to observe the complete laminar structures as shown in Figure 6 (b, c, d).

In ceramic petrography it is usual to encounter the characteristics of natural and induced carbonates (pyrogenic recrystallization); however, it is very difficult to distinguish with optical microscopy. Cau-Ontiveros et al. (2002) described the presence of "micritic clots", which they observed as crypto-microcrystalline masses of calcite that partially formed around primary carbonates during the process of their exposure to fire. According to these authors, burning the carbonates produces an insoluble residue, which may react with the clay matrix paste to generate minerals from the pyroxene group. Experimental studies under controlled conditions suggest reactions similar to pyrometamorphism (Cultrone et al., 2001; Grapes, 2010); nevertheless, it is still controversial. Microcrystalline carbonates are present after burning organic material as shown in Figure 6 (e, f).

\subsection{RELICT ORGANIC COMPONENTS FROM SOIL}

The soil used to produce the clay matrix of the paste could contain a record of the stable components as evidence of colonization by organisms; such as plant remains.

One of the most important types of biological evidence of the soil origin in the ceramic are the phytoliths, which are inorganic silica bodies formed in 

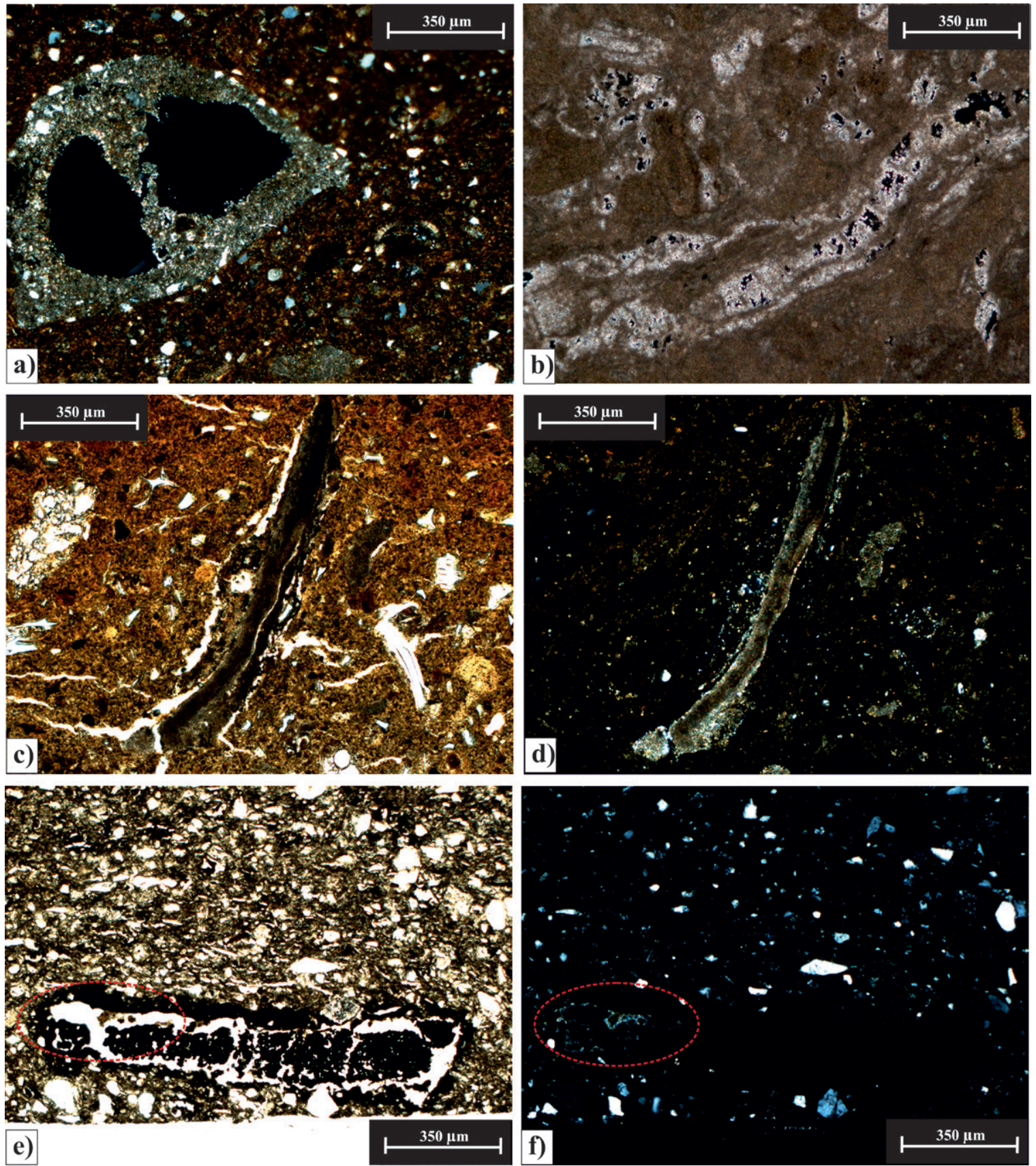

Figure 6 Diversity of carbonates in ceramic paste.

(a) Cross-polarized light (XPL). Organism of primary carbonate (bioclast) in Dzibalche Bayo fine ceramic from Jaina, Campeche. The dominance of micrite and some small microsparite areas are evident.

(b) XPL. Micromorphology of calcrete or caliche from Playa del Carmen, Quintana Roo. From the top of the Pleistocene aeoliansedimentary sequence (Ward, 1985; Cabadas-Báez et al., 2010a). The dominance of a micritic matrix with recrystallization inside pores is the characteristic feature. The banded or laminar morphology suggest root traces by vegetal colonization during the platform subaerial exposure. Another cause of this structure could be the presence of algae-fungi communities.

(c, d) Caliche fragment as temper in the Chabihau Red Specular ceramic (Baca group) from Jaina, Campeche. Laminar or banded morphologies are evident in both images. (c) Plane-polarized light (PPL). (d) XPL. The micritic carbonates display the high interference color. Isotropic volcanic glass temper can also be seen.

(e, f) Charcoal relict in the Chablekal Gray fine ceramic from Xcambó, Yucatán. The charcoal was a plant tissue from the soil vegetation, incidentally used as temper and subsequently burned during the firing of the ceramic. (e) PPL. (f) XPL. The red circle denotes the presence of micritic carbonates generated during exposure to fire. 
plant tissues. Phytoliths are formed in specific sites within the plant, such as leaves, stem, and inflorescence, among others. They remain relatively stable in the soil when the plant dies and their morphology is useful for paleoenvironmental reconstructions (Piperno, 2006). Phytoliths were found in the ceramic paste of the Yaxchilán samples (Figure 7a, b). These components had already been described by Bishop (1994) in the Usumacinta region. The presence of phytoliths is evidence of an organic A horizon soil, colonized by a plant cover (Solís-Castillo et al., 2015).

Phytoliths or complete opal tissues are easily confused with volcanic glass fragments because they share similar optical properties, such as the refraction index (less than 1.54) and isotropy (Jack, 2005). Phytoliths, however, have distinctive characteristics: their pinkish coloring, ornaments in certain cases (cavities) and the inclusions of fine organic material (dark pigmentation) (Figure 7a, b). One of the goals for ceramic provenance analysis is to extract and compare phytoliths or other opal biomorphs (for example diatoms; Obando et al., 2011) in soil raw material and in the corresponding pottery to try to trace their permanency. In general, charcoal has not been a common choice of tempering material in the production of pottery and is associated with only a few cultures (Wallis et al., 2011). Most plant residues found in Maya ceramics were probably part of natural soil vegetation, susceptible to burning during the firing of the ceramics. Some larger plants, though, maintain a degree of stability when affected by fire (Canti, 2003), and it may be possible to observe part of their cell structure and tissue (Figure 7e, f, g).

Indirectly, void morphology (mainly vesicular and elliptical) and void wall impregnations (Figure 7c, d) may support the presence of burned organic material as suggested by Laviano and Muntoni (2006), Reedy (2008), and Quinn (2013). The description of void morphology and its relationship to specific plant relicts in ceramics (van Doosselaere et al., 2014) are still poorly described and understood in Maya ceramic petrography.

\subsection{BIREFRINGENGE PATTERNS IN THE GLAY MATRIX: DESGRIPTION, PROPERTIES, AND RELATION WITH SOIL B-FABRIC}

The majority of the petrographic descriptions of Maya ceramics have focused on the coarse mineral components, with few characterizations of the fine clay matrix. The most interesting aspect of the clay matrix is the absence or presence of birefringence with crossed polarizers. Aylmore and Quirk (1959) (in Stoops, 2003) proposed the term "domain" when describing the optically anisotropic behavior of clay minerals when the crystals lie in a parallel orientation.

For Whitbread (1986) the term b-fabric, used to describe the birefringent fabric in soil micromorphology (Bullock et al., 1985; Stoops, 2003), could be applied to describe ceramic fabrics and their birefringent domains. It is important to keep in mind that the clay components exhibited in the fine mass or groundmass of the soil could be isotropic through masking of the birefringence by opaque and amorphous material (Fitzpatrick, 1984). For Whitbread (1986) this situation might be considered to describe the optical state of a fired clay matrix, but the assumption remains that the domains themselves are unaltered. The same author suggested the use of the terms "optically active" or "optically inactive" to describe the state of the fine clay matrix in ceramics. Figure $8(\mathrm{k}, \mathrm{l})$ shows an example of an inactive b-fabric, where the birefringence is evident in silt- and sand-size mineral particles.

Ceramic body regions given special attention with regard to the b-fabric are the slip and the core (Figure $8 \mathrm{c}, \mathrm{d}, \mathrm{e}, \mathrm{f})$. The most significant characteristics are striations or elongated areas at least $30 \mu \mathrm{m}$ of length generated by the juxtaposition of oriented clay (Figure $8 \mathrm{~g}, \mathrm{~h}$ ). In a natural soil body, the striation patterns are typical of soils with vertic properties (IUSS Working Group WRB, 2015), due to the expansion-contraction of clay minerals responding to pronounced seasonal weather changes (Dalrymple and Jim, 1984). Different studies of soils close to the archeological sites have shown 

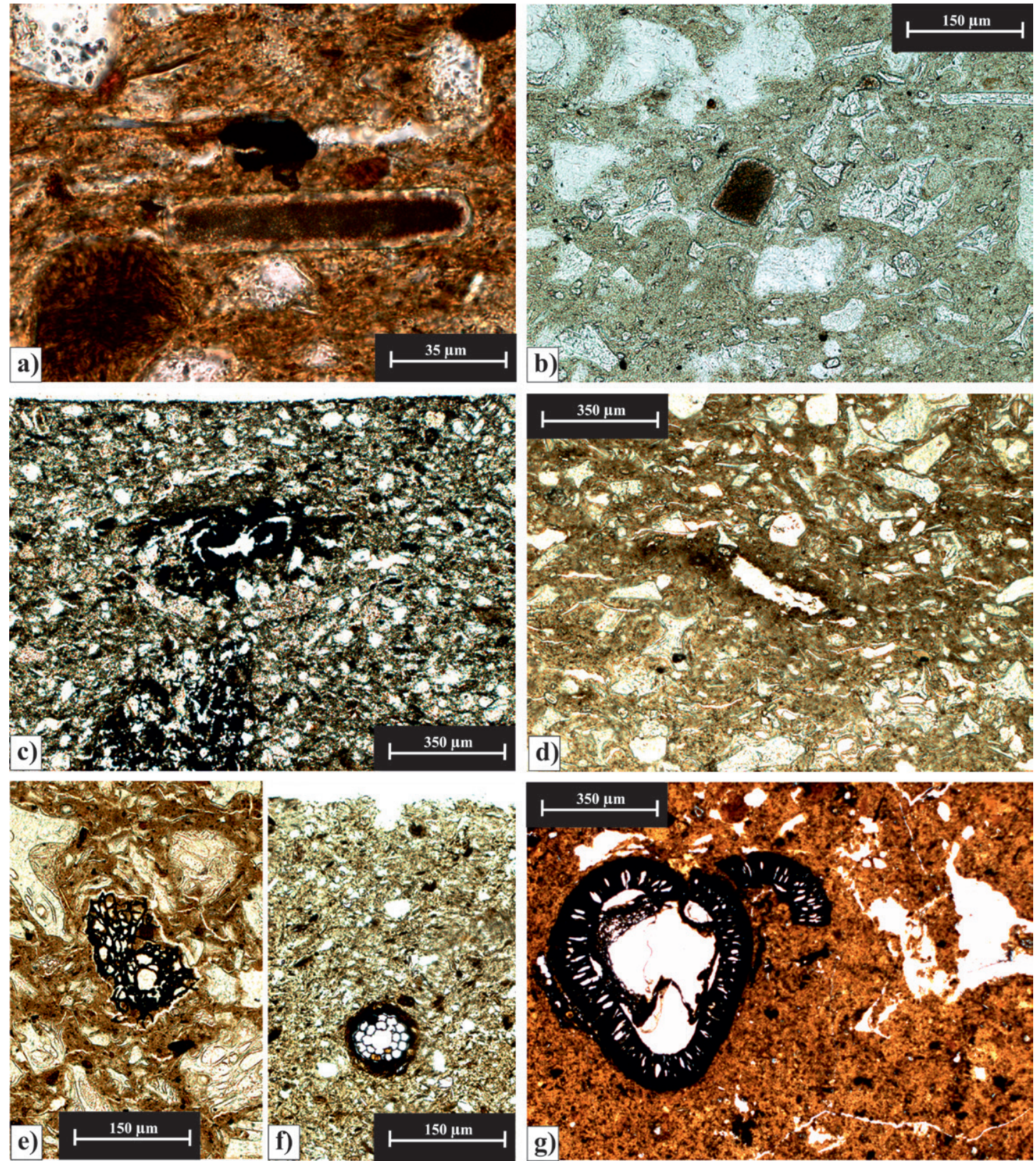

Figure 7 Vegetation remnants.

(a, b) Phytoliths in fine matrix of Lucha incised ceramic, Yaxchilán, Chiapas. Plane-polarized light (PPL). Elongated (a) and fan morphologies (b) under the classification of Twiss (1992). In PPL, phytoliths are recognizable for their high relief and the pinkish dark color from the occlusion of organic matter, contrasting with the volcanic glass shards.

(c) PPL. Degraded vegetation remnants in Coloradas Ribbed ceramic (Tsicul group) from Xcambó, Yucatán. In the center of the photomicrograph an opaque circular "mottle" is evident with an ellipsoidal shape and an apparent fibrous core. Below this "mottle" a dark impregnation suggests the mobilization of organic remains in the ceramic paste. The fibrous aspect could be related to degradation by combustion.

(d) PPL.Vesicular void with organic matter impregnation in Lucha Incised ceramic from Yaxchilán, Chiapas. In the center of the photomicrograph, an ellipsoidal void has its walls impregnated with a fine opaque material, which could be related to the combustion of vegetal components.

(e) PPL. Vegetal remain with well-preserved cellular structure in Lucha incised ceramic from Yaxchilán, Chiapas.

(f) PPL. Vegetal remain with well-preserved cellular structure in Chablekal Costa ceramic from Uaymil, Campeche.

(g) PPL. Vegetal remain in A horizon from a Chromic Luvisol soil from Kantunil Kin, Quintana Roo. The structure was degraded and fragmented, but some center areas could be associated with root traces. 
the presence of clay minerals with expansioncontraction properties (Isphording, 1978; Wilson, 1980; Dunning, 1992; Bautista et al., 2005, 2011; Cabadas-Báez et al., 2010b; Simms et al., 2013). In particular, the micromorphology of clayed soils studied by Cabadas-Báez et al. (2010b) denoted strong vertic properties related to its evolutionary trend (Figure 8a, b).

It is possible that part of the original pattern that generated striations with oriented clay in the soil has been inherited by the ceramic paste (originally conserved in the clay temper and subsequently degraded during processing and molding of the paste). At the same time, the clay's mineralogy may have responded to the friction-pressure process caused by human intervention, especially in the surface finishes. This is one aspect of Maya ceramic petrography that has been scarcely studied and poorly understood, being partially interpreted in only a few works (e.g., Obando and Jiménez, 2016). In Yaxchilán ceramic samples (Figure 8e, f, $i, j)$ the slip shows a clear and higher presence of oriented striations with particular patterns, which vary between net-like, grain-striated, circular, parallel, and concentric. In areas in the center or core of the ceramic, the striations are thinner and often
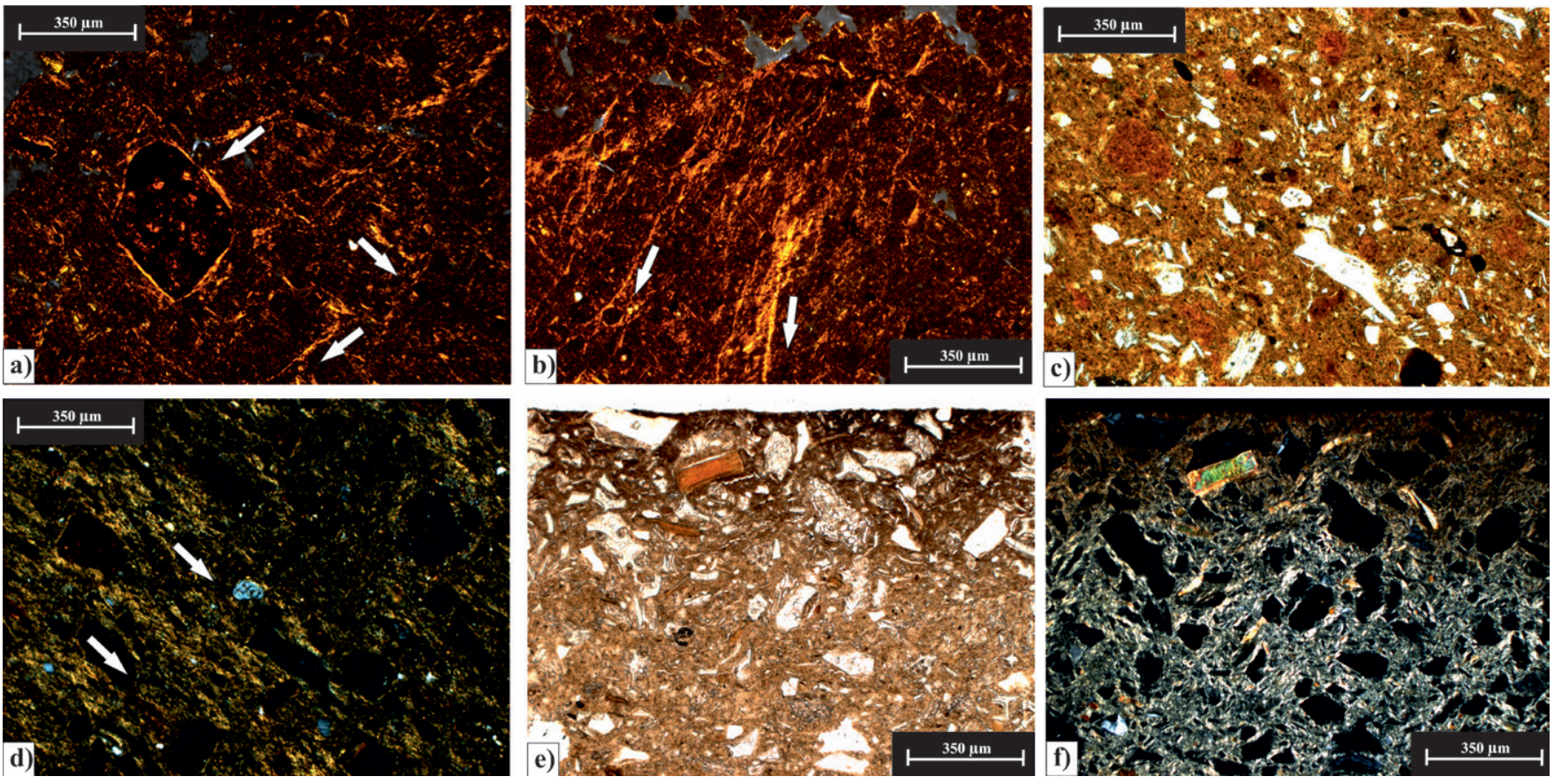

Figure 8 Birefringence patterns (b-fabric) in soils and ceramics.

(a) Cross-polarized light (XPL). Granostriated and cross-striated b-fabrics in Bt horizon (Chromic Luvisol) from Bolonchen, Campeche. The white arrows mark the preferential direction of the oriented clay particles. A typical Fe-nodule displays a rim with striations. Photomicrograph with substage condenser.

(b) XPL. Parallel-striated b-fabric in Bt horizon (Chromic Luvisol) from Kantunil Kin, Quintana Roo. In the center of the photomicrograph, the thickness in the striations is notable. Photomicrograph with substage condenser.

(c, d) Parallel-striated b-fabric in Nimún Brown ceramic (Nimún group) from Jaina, Campeche. (c) Plane-polarized light (PPL). Particle orientation, even in the coarse fraction, is imperceptible. (d) XPL. Parallel coarse striations are evident together with interlayered volcanic glass and "soil blocks" (rounded reddish-brown particles) poorly incorporated to the paste. Photomicrograph in the core of the ceramic.

(e, f) Granostriated b-fabric in the external surface (slip) of Infierno Black ceramic from Yaxchilán, Chiapas. (e) PPL. The color transition of the clay matrix, from the top to the core of the ceramic, is clear. (f) XPL. The granostriated b-fabric is dominant around the volcanic glass temper and some biotite crystals. The change in color is abrupt in the clay matrix; however, the b-fabric pattern is the same throughout the sample. Photomicrograph with substage condenser.

Continued on the next page. 

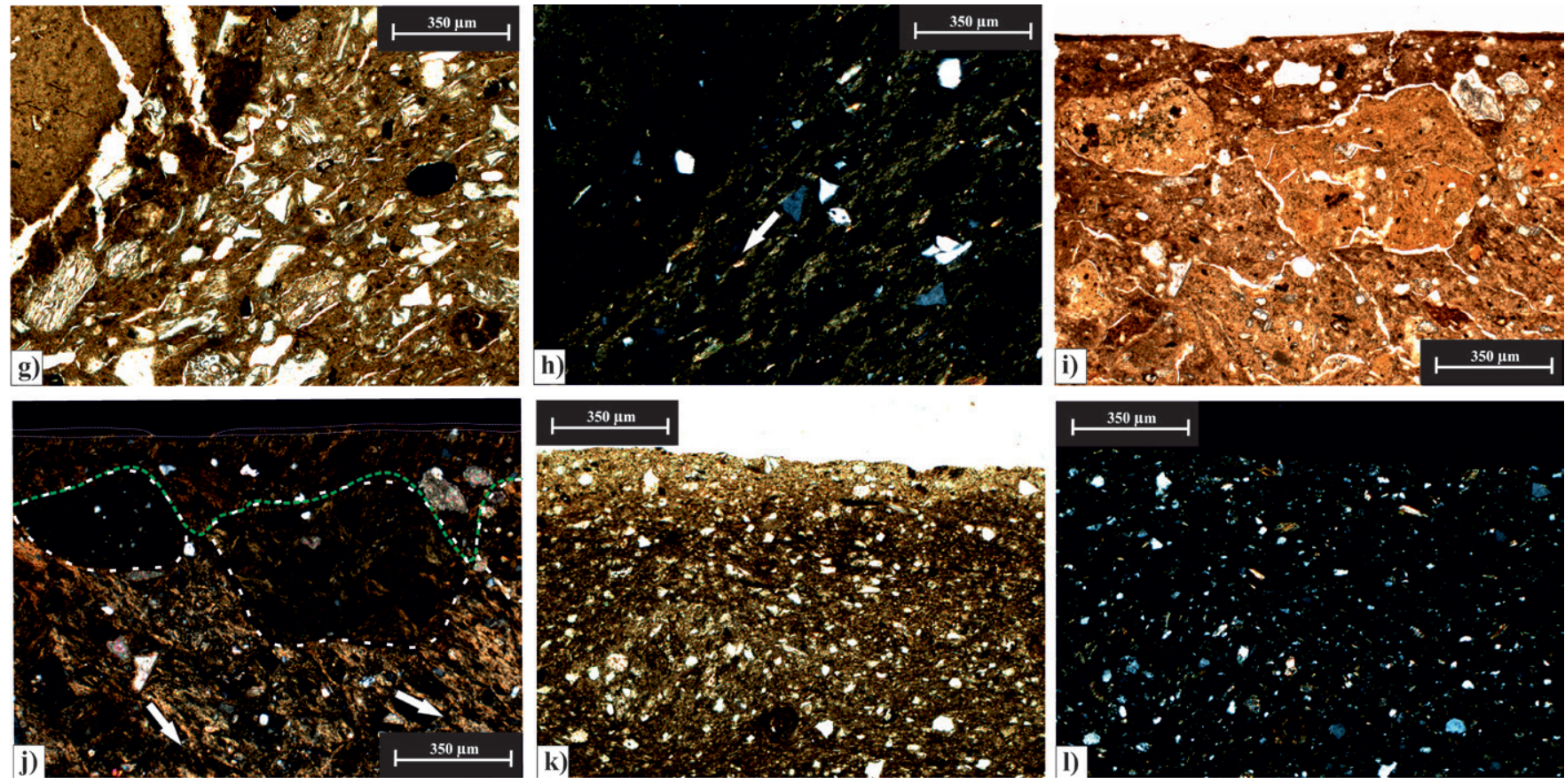

Figure 8 (Continuation) Birefringence patterns (b-fabric) in soils and ceramics.

(g, h) Parallel-striated b-fabric in Lucha Incised ceramic from Yaxchilán, Chiapas. (g) PPL. In the upper right corner, a brownish dark clay material is visible, probably associated with clay temper ("block soil") weakly incorporated in the ceramic paste. (h) XPL. The parallel striations around the clay temper denotes the hardness of the material or resistance to compaction during the ceramic paste preparation. The white arrow marks the general orientation of the b-fabric.

(i, j) Color heterogeneity in clay ceramic matrix in Lucha Incised ceramic from Yaxchilán, Chiapas. (i) PPL. (j) XPL. A weakly parallelstriated $b$-fabric in the lower part of the image is observable. The dashed white line denotes the limit of grog used as temper with its own b-fabric (a very weak granostriated pattern). On the surface, apparently, a transitional darkish brown color (limited by the green dashed line) affected the parallel-striated pattern. Finally, in the top of the image, a very thin colored slip (probably clay with Fe enrichment) presents a very weak birefringence, even with tendency to isotropy.

$(k, \mathrm{l})$ Undifferentiated b-fabric in Xuxac Incised ceramic (Tsicul group) from Xcambó, Yucatán. (k) PPL. A darkish brown matrix is dominant, with the exception of the surface, where the color transition to pale brownish is clear. (I) XPL. Most of the ceramic matrix presents an absence of interference color.

demonstrate an irregular or pore-striated pattern. In this case, we suggest that the clear difference between core and slip is due to the relative pressure applied by the potter's fingers during wedging.

Several authors described the birefringent domains as the result of the presence of "mica" or "sericitic" components (Chung, 2009). Obando et al. (2011) and Obando and Jiménez (2016) even suggested the term "phillomorphism" to describe the grade of glint in the ceramic matrix. For Quinn (2013) it is possible to estimate the equivalent firing temperature of ancient ceramics in thin section by the observation of thermally induced changes in the b-fabric clay matrix. However, we suggest the observable patterns be interpreted with caution in the absence of X-ray diffraction and microprobe data.

\subsection{MICROMORPHOLOGY AND GERAMIC ALTERATION BY SOIL GONTEXT}

As suggested by Zalasiewicz et al. (2014a), technofossils such as ceramics will degrade physically and chemically over time, especially as the deposits that they lie on or that enclose them undergo erosion. Long-term preservation of ceramics requires burial. Once buried underground, rates of chemical and physical alteration, as with natural sediments, will be controlled by moisture, temperature, oxygen, and pH (Zalasiewicz et al., 2014a). 
The correct identification and discrimination of altered materials in Maya ceramic petrography is essential not only to understand the physical and chemical properties of the artifacts, but also because it can easily lead to incorrect pottery classifications and false ware-group assignments (Tschegg, 2009). In the petrographic reports from the Maya area, information from the burial context of the ceramic material is lost through treatments to which the samples are subjected in order to "clean" them for a better interpretation (Vaughan, 1995).

In particular, for the samples studied at Yaxchilán and Jaina, in order to distinguish carbonates in the slip (Figure 9b, c, d) from carbonates produced by alteration, it is necessary to observe their distribution. With the latter, their location along fractures and porous zones of the paste is evidence of interaction with pedogenic or secondary carbonates (leachates sourced from deposits rich in calcium carbonate may produce cements that can ultimately bind and solidify ceramic fragments).

It is of utmost importance to know whether ceramic sherds have a deliberate slip or not, since this is a record of the level of technological sophistication achieved at a particular time by the potters (Tschegg, 2009). In the Maya region, the soil carbonation processes caused the artifacts to inherit several characteristics. The importance of sherd surface alteration urgently needs to be considered in the classification of ware groups by their surface attributes.

If possible, the analysis of a micromorphological sample that includes the complete structure of the soil or sediment surrounding the ceramic fragments is recommended (Figure $9 \mathrm{a}, \mathrm{b}$ ). By doing so, it is possible to conserve the unaltered features of the ceramics at their precise stratigraphic position. It may also be possible to determine if part of the coatings on pore walls corroborate the context of organic activity in the soil, which may include the effects of bioturbation (e.g., the presence of chambers with excrement infillings) (Figure 9e), something very common in surficial and organic soil horizons (Figure 9f).

\section{Conclusions}

Earth scientists are using archaeological materials (along with other stratigraphic, geochemical and biological evidences) to date their version of the start and development of the Anthropocene (Ruddiman, 2003; Edgeworth, 2014). Polycrystalline materials such as ceramics serve as obvious Anthropocene marker "lithologies" (Zalasiewicz et al., 2014a; Hazen et al., 2017). Minerals and organic components are combined in ceramics in a diversity of patterns or pastes to produce a great variety of pottery types that change through time and through cultural affiliation.

The primary objective of soil micromorphology and ceramic petrography in archaeology is the examination of modified geologic materials composed of sand, silt, and clay-sized particles (Josephs, 2005). Understanding the micromorphological characteristics of the pottery requires familiarity with the nature of the soils used to make the ceramic (Wieder and Adan-Bayewitz, 2002). The soil formation processes leave their imprint in different proportions in ceramic: clay illuviation, shrink-swell capacity (vertic properties), redox environment, and weathering of rock forming minerals (including phases associated with artifact disuse, and even burial by soil).

Maya soil resources available in the landscape were usually varied and rarely restricted to a particular deposit; the variations in the composition of the ceramic fabric indirectly reflect differing distributions of geological resources and the management of raw materials (Arnold, 2000; Buxeda et al., 2003). Every component described denotes a preferential selection of the natural resources based on their behavior according to certain technical needs that are related to manufacturing processes and the use of artifacts; hence, potters can use or discard any particular material, but they also modify its qualities through experimentation and mixing the soil with other components (Cuomo Di Caprio and Vaughan, 1993; Rice, 1996; Arnold, 

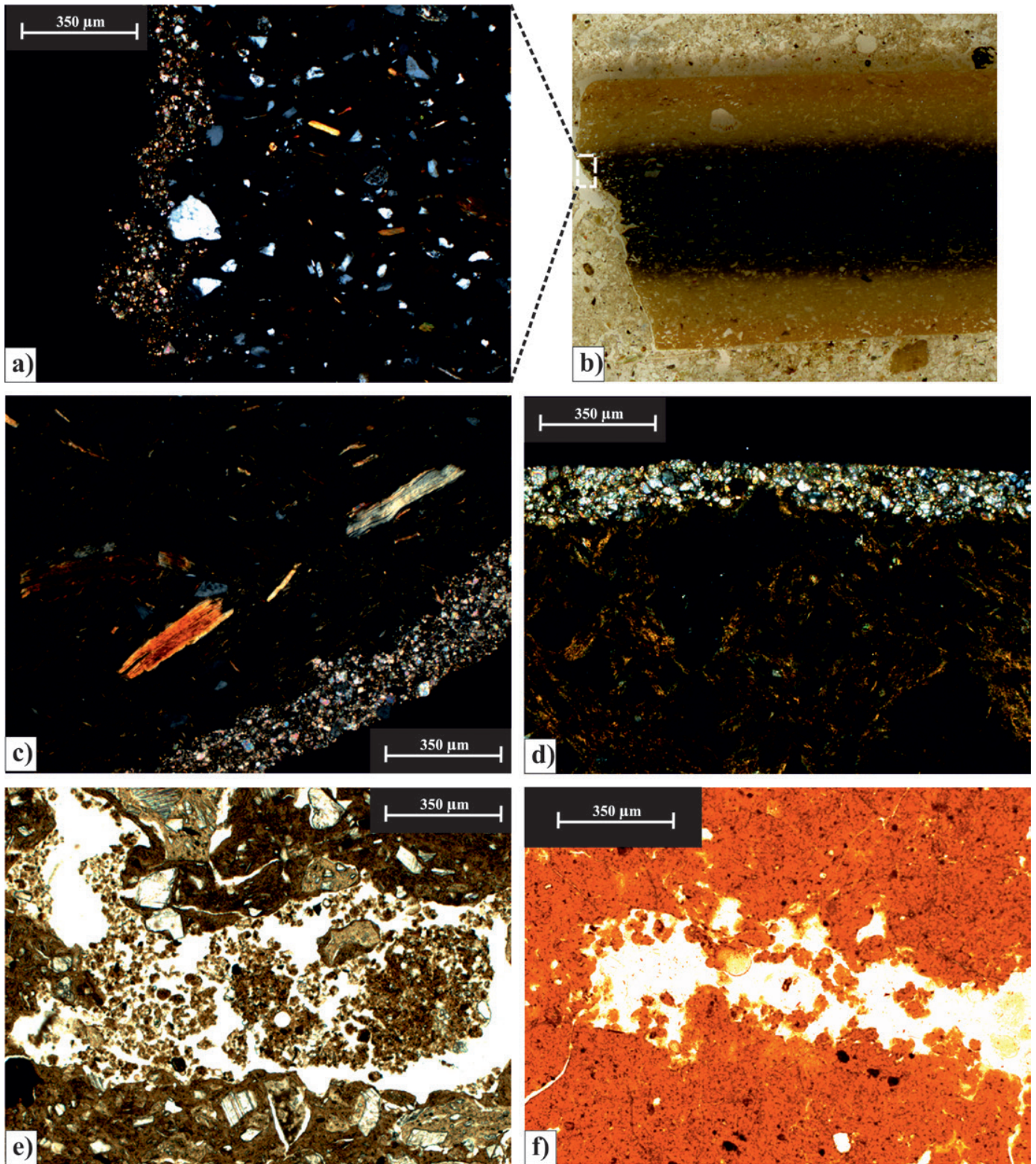

Figure 9 Alterations by the soil context.

(a, b) Carbonate alteration on fracture of Trapiche Incised ceramic (Altar group) from Yaxchilán, Chiapas. (a) Cross-polarized light (XPL). With the highest birefringence, the micritic and microsparitic carbonates along the vertical fracture are more evident. The contact between the carbonates and the ceramic paste is abrupt and with a wavy morphology, including the variable thickness of the accumulation. (b) Plane-polarized light (PPL). Scanned thin section with the ceramic sherd included in the soil natural groundmass. (c) XPL. Carbonate slip on surface of Silk Grass ceramic (Sotero Red-Brown group) from Yaxchilán, Chiapas. The highest birefringence of the microsparite, follows the curved surface of the ceramic with an abrupt contact. The mica crystals are parallel to the surface and the slip. The isotropic grains denotes the dominant presence of volcanic glass temper.

(d) XPL. Carbonate slip on surface of Baca Red ceramic (Baca group) from Jaina, Campeche. The continuous microsparitic horizon with an abrupt contact with the rest of the ceramic paste is evident. Most of the temper is volcanic glass, and the ceramic clay matrix presents a weak granostriated b-fabric.

(e) PPL. Excremental infillings in a pore of the Sierra Rojo ceramic (Sierra group). The excremental pedofeatures are typical in the A soil horizons. The burial context produced bioturbation in the unstable porosity of the ceramics. The vesicular void was probably a plant residue where the organism resided and fed (part of a chamber). The coalescence of the coprolites generates an accretionary aspect (spherical masses).

(f) PPL. Excremental infillings in an A horizon soil (Chromic Luvisol) from Kantunil Kin, Quintana Roo. In spite of high content in clay fraction, the organism may produce chambers and contribute to the soil aggregation and microstructure. 
2000; Hein et al., 2004; Mahmoudi et al., 2008; Albero-Santacreu, 2014).

\section{Acknowledgements}

This work would not have been possible without the support of diverse institutions: Centro INAH Campeche, Centro INAH Yucatán, Facultad de Ciencias Antropológicas UADY, and the Smithsonian Institution. Our thanks to Coordinación Nacional de Arqueología for the acquisition of a part of these ceramic materials. We extend our thanks to the project PRIORI (Programa de Impulso y Orientación a la Investigación) with the program "Jóvenes Investigadores" of the Universidad Autónoma de Yucatán. Special thanks to CONAGyT by Iliana Ancona for the support with the stipendium for Postgraduate Studies. Our gratitude to the technicians in the Thin Section Workshop in the Soil Science Department of the Institute of Geology at UNAM: M. Sc. Jaime Díaz Ortega and Eligio Jiménez $z^{\dagger}$ for the careful preparation of every thin section used in this work. We thank Jorge R. Alcalá for the fieldwork support in soil survey. We appreciate the criticism of Marie-Agnès Courty to improve the manuscript and the careful review of Guillermo Acosta Ochoa and anonymous reviewers. Very special thanks to Itzel Báez for her valuable assistance in the bibliographic research at several libraries in London.

\section{References}

Aguayo, G.J.E., Bello, M.R., del Vecchio C., M.A., Araujo, M.J., Basañez, L.M.A., 1980, Estudio sedimentológico en el área Tulúm-CancúnIsla Mujeres, Estado de Quintana Roo, México: Boletín de la Sociedad Geológica Mexicana, 41, 15-32.

Albero-Santacreu, D., 2014, Materiality, Techniques and Society in Pottery Production. The Technological Study of Archaeological Ceramics through Paste
Analysis: Monograph, De Gruyter, Open Access, Warsaw/Berlin, 336 p.

Arnold, D.E., 1985, Ceramic theory and cultural process: Cambridge, Cambridge University Press, $284 \mathrm{p}$.

Arnold, D.E., 2000, Does the standardization of ceramic really mean standardization?: Journal of archaeological method and theory, 7, 333-375.

Aylmore, L.A.G., Quirk, J.P., 1959, Swelling of clay-water systems: Nature, 183, 1752-1753.

Barnosky, A.D., 2014, Paleontological evidence for defining the Anthropocene, in Waters, C.N., Zalasiewicz, J., Williams, M., Ellis, M.A., Snelling, A.M. (eds.), A stratigraphical basis for the Anthropocene, Geological Society Special publication 395: London, The Geological Society, 149-165.

Bautista, Z.F., Palma, L.D., Huchin, M.W., 2005, Actualización de la clasificación de los suelos del estado de Yucatán, in Bautista, F., Palacio, G. (eds.), Caracterización y manejo de suelos en la Península de Yucatán: implicaciones agropecuarias, forestales y ambientales: México, Universidad Autónoma de Campeche, Universidad Autónoma de Yucatán, Instituto Nacional de Ecología, 105-122.

Bautista, F., Palacio, A.G., Quintana, P., Zinck, J.A., 2011, Spatial distribution and development of soils in tropical karst areas from the Peninsula of Yucatan, Mexico: Geomorphology, 135, 308-321.

Beach, T., Luzzadder-Beach, S., Cook, D., Dunning, N., Kennett, D.J., Krause, S., Terry, R., Trein, D., Valdez, F., 2015, Ancient Maya impacts on the Earth's surface: An Early Anthropocene analog?: Quaternary Science Reviews, 124, 1-30.

Bishop, R.L., 1994, Pre-Columbian pottery: research in the Maya region, in Scott, D.A., Meyers, P. (eds.), Archeometry of preColumbian sites and artifacts: Los Angeles, Getty Conservation Institute, 15-65. 
Bishop, R. L., 2014, Instrumental approaches to understanding Mesoamerican Economy: Elusive promises: Ancient Mesoamerica, 25, 251-269.

Bishop, R.L., Sears, R.L., Blackman, M.J., 2005, A través del río del cambio: Estudios de Cultura Maya, 26, 17-40.

Bronger, A., Sedov, S., 2003, Vetusols and paleosols: natural versus man-induced environmental change in the Atlantic coastal region of Morocco: Quaternary International, 106107, 33-60.

Bullock, P., Fedoroff, N., Jongerius, A., Stoops, G., Tursina, T., Babel, U., 1985, Handbook for soil thin section description: Wolverhampton, Waine Research Publications, 152 p.

Buxeda I Garrigós, J., Cau Ontiveros, M.A., 1995, Identificación y significado de la calcita secundaria en cerámicas arqueológicas: Complutum, 6, 293-309.

Buxeda, J., Cau Ontiveros, M.A., Kilikoglou, V., 2003, Chemical variability in clays and pottery from a traditional cooking pot production village: Testing assumptions in Pereruela: Archaeometry, 45, 1-17.

Cabadas-Báez, H.V., Solleiro-Rebolledo, E., Sedov S., Pi, T., Gama-Castro, J., 2010a, Pedosediments of karstic sinkholes in the eolianites of NE Yucatan: a record of Late Quaternary soil development, geomorphic processes and landscape stability: Geomorphology, 122, 323-337.

Cabadas-Báez, H.V., Solleiro-Rebolledo, E., Sedov, S., Pi, T., Alcalá, J.R., 2010b, The complex genesis of red soils in Peninsula de Yucatán, Mexico: mineralogical, micromorphological and geochemical proxies: Eurasian Soil Science, 4, 1-19.

Cabadas-Báez, H.V., Solís-Castillo, B., SolleiroRebolledo, E., Sedov, S., Leonard, D., Teranishi-Castillo, K., Liendo, R., Korneychik, O., 2017, Reworked volcaniclastic deposits from the Usumacinta river, Mexico: A serendipitous source of volcanic glass in Maya ceramics: Geoarchaeology, 32, 382-399.

Canti, M.G., 2003, Aspects of the chemical and microscopic characteristics of plant ashes found in archaeological soils: Catena, 54, 339-361.

Canti, M.G., 2017, Charred plant remains, in Nicosia, G., Stoops, G. (eds.), Archaeological soil and sediment micromorphology: Oxford, Wiley-Blackwell, 141-142.

Carr, M., Stoiber, R., 1990, Volcanism, in Dengo, G., Case, J.E. (eds.), The Caribbean region Geology of North America, v.H.: Boulder, Geological Society of America, 375-392.

Casadio, R., Fabbri, B., Maldera, R., 1991, Ancient fire resistant pottery from Emilia Romagna (Italy), in Pernicka, E., Wagner, G.A., (eds.), Archeometry'90: Basel, Switzerland, Birkhauser Verlag, 237-246.

Castro-Dorado, A., 1989, Petrografía básica. Texturas, clasificación y nomenclatura de rocas: Madrid, Paraninfo, 143 p.

Cau Ontiveros, M.A., Day, P.M., Montana, G., 2002, Secondary calcite in archaeological ceramics: evaluation of alteration and contamination processes by thin section study, in Kilikoglou, V., Hein, A., Maniatis, Y. (eds.), Modern trends in ancient ceramics: Oxford, Archaeopress, 9-18.

Chung, H., 2009, La cronología de Chichén-Itzá: Paju, Korea Studies Information, 276 p.

Chung, H., Song, Y., 2014, The meaning of volcanic ash characteristics found in the archaeological pottery of Chichen Itza, Yucatan, Mexico: Mediterranean Archaeology and Archaeometry, 14, 155-167.

Cobos, R., 2005, Puertos Marinos Mayas del Clásico: Uaymil, Costa Norte de Campeche: Fundación para el Avance de los Estudios Mesoamericanos Inc., Technical report, available at <http://www.famsi.org/ reports/00013es/00013esCobos01.pdf>, accessed April 17, 2017. 
Courty, M.A., Goldberg, P., Macphail, R., 1989, Soils and micromorphology in archaeology: Cambridge, Cambridge University Press, $364 \mathrm{p}$.

Crutzen, P.J., 2002, Geology of mankind: Nature, 415, 23.

Cultrone, G., Rodrígez-Novarro, C., Sebastian, E., Cazalla, O., De la Torre, M.J., 2001, Carbonate and silicate phase reactions during ceramic firing: European Journal of Mineralogy, 13, 621-624.

Cuomo Di Caprio, N., Vaughan, S., 1993, An experimental study in distinguishing grog (chamotte) from argillaceous inclusions in ceramic thin sections: Archeomaterials, 7, 21-40.

Dalrymple, J.B., Jim, C.Y., 1984, Experimental study of soil microfabrics induced by isotropic stress of wetting and drying: Geoderma, 34, 43-68.

de Pablo, L., 1996, Palygorskite in EoceneOligocene lagoonal environment, Yucatan, Mexico: Revista Mexicana de Ciencias Geológicas, 13, 94-103.

Delvigne, J.E., 1998, Atlas of micromorphology of mineral alteration and weathering: Ontario, Canada Mineralogical Association of Canada and ORSTOM editions, 494 p.

Dunning, N.P., 1992, Lords of the hills: ancient Maya settlement in the Puuc Region, Yucatan, Mexico: Madison, Prehistory Press, Monographs in World Archaeology 15, 303 p.

Edgeworth, M., 2014, The relationship between archaeological stratigraphy and artificial ground and its significance in the Anthropocene, in Waters C.N., Zalasiewicz, J., Williams, M., Ellis, M.A., Snelling, A.M. (eds.), A stratigraphical basis for the Anthropocene, Geological Society Special publication 395: London, The Geological Society, 91-108.

Fabbri, B., Gualtieri, Shoval, S., 2014, The presence of calcite in archaeological ceramics: Journal of the European Ceramic Society, 34, 1899-1911.

Fitzpatrick, E.A., 1984, Micromorphology of soils: London, Chapman \& Hall, 434 p.

Flügel, E., 2010, Microfacies of carbonate rocks: Analysis, interpretation and application. (Second Edition): Berlin Heidelberg, Springer-Verlag, $984 \mathrm{p}$.

Ford, A., Glicken, H., 1987, The significance of volcanic ash tempering in the ceramics of the Central Maya Lowlands, in Rice, P.M., Sharer, R.J. (eds.), Maya ceramics: Papers from the 1985 Maya Ceramic Conference: Oxford, Archaeopress, 479-502.

Ford, A., Rose, W.I., 1995, Volcanic ash in ancient Maya ceramics of the limestone Lowlands: Implications for prehistoric volcanic activity in the Guatemalan Highlands: Journal of Volcanology and Geothermal Research, 66, 149-162.

Ford, A., Spera, F., 2007, Fresh volcanic glass shards in the pottery sherds of the Maya Lowlands: Research Reports in Belizean Archaeology. Institute of Archaeology, NICH, Belize, 4, 111-118.

Ford, A., Spera, F.J., Christensen, C., 2017, Petrograpy first. Issues of identification and sourcing volcanic ash temper in Maya pottery, in Ownby, M.F., Druc, I.C., Masucci, M.A. (eds.), Integrative approaches in ceramic petrography: Salt Lake City, USA, The University of Utah Press, 8-23.

Ford, J.R., Price, S.J., Cooper, A.H., Waters, C.N., 2014, An assessment of lithostratigraphy for anthropogenic deposits, in Waters C.N., Zalasiewicz, J., Williams, M., Ellis, M.A., Snelling, A.M. (eds.), A stratigraphical basis for the Anthropocene, Geological Society Special publication 395: London, UK, The Geological Society, 55-89.

Gillot, G., 2014, The use of pozzolanic materials in Maya mortars: new evidence from Río Bec (Campeche, Mexico): Journal of Archaeological Science, 47, 1-9. 
Goldberg, P., Berna, F., 2010, Micromorphology and context: Quaternary International, 214, 56-62.

Grapes, R., 2010, Pyrometamorphism: Berlin Heidelberg, Springer-Verlag, 365 p.

Haff, P.K., 2014, Technology as a geological phenomenon: Implications for human well-being, in Waters, C.N., Zalasiewicz, J., Williams, M., Ellis, M.A., Snelling, A.M. (eds.), A stratigraphical basis for the Anthropocene, Geological Society Special publication 395: London, UK, The Geological Society, 301-310.

Hazen, R.M., Grew, E.S., Origlieri, M.J., Downs, R.T., 2017, On the mineralogy of the "Anthropocene Epoch": American Mineralogist, 102, 595-611.

Hein, A., Day, P.M., Cau, M.A., Kilikoglou, V., 2004, Red clays from Central and Eastern Crete: geochemical and mineralogical properties in view of provenance studies on ancient ceramics: Applied Clay Science, 24, 245-255.

Heraud, P.M., 1996, Le Karst du Yucatan: Pays des Mayas. Bordeaux: Presses Universitaires de Bordeaux, Collection Scieteren, 284 p.

Howard, J.L., Orlicki, K.M., 2016, Composition, micromorphology and distribution of microartifacts in anthropogenic soils, Detroit, Michigan, USA: Catena, 138, 103-116.

Howie, L, 2012, Ceramic change and the Maya collapse. A study of pottery technology, manufacture and consumption at Lamanai, Belize: Oxford, Archaeopress, 244 p.

Iceland, H.B., Goldberg, P., 1999, Late-Terminal Classic Maya pottery in Northern Belize: a petrographic analysis of sherd samples from Colha and Kichpanha: Journal of Archaeological Science, 26, 951-966.

Ismail-Meyer, K., 2017, Plant remains, in Nicosia, C., Stoops, G. (eds.), Archaeological soil and sediment micromorphology: Oxford, WileyBlackwell, 121-135.
Isphording, W.C., 1974, Weathering of Yucatan limestones: the genesis of terra rosas, in Weidie, A.E. (ed.), Field seminar on water and carbonates of the Yucatan Peninsula, Mexico. Field trip 2: New Orleans, New Orleans Geological Society and Geological Society of America, 78-93.

Isphording, W.C., 1978, Mineralogical and physical properties of Gulf limestone soils: Transaction-Gulf Coast Association of Geological Societies, 28, 201-214.

Isphording, W.G., Wilson, E., 1974, The relationship of "volcanic ash", Sak Lu'um and paligorskite in northern Yucatan Maya ceramics: American Antiquity, 39, 483-488.

IUSS Working Group WRB, 2015, World Reference Base for Soil Resources 2014, update 2015. International soil classification system for naming soils and creating legends for soil maps: Rome, Food and Agriculture Organization of the United Nations, World Soil Resources Reports No. 106, 192 p.

Jack, S., 2005, The application of microtephrochronology to archaeology: a critical assessment with reference to Maya archaeology: Oxford, University of Oxford, master in science thesis, $137 \mathrm{p}$.

Jiménez-Álvarez, S., 2002, La cronología cerámica del puerto maya de Xcambó, costa norte de Yucatán: Complejo cerámico Xcambó y complejo cerámico Cayalac: Mérida, México, Universidad Autónoma de Yucatán, Facultad de Ciencias Antropológicas, undergraduate thesis, $311 \mathrm{p}$.

Jiménez-Álvarez, S., Ceballos, T., Sierra-Sosa, T., 2000, Las insólitas cerámicas del litoral noroeste de la península de Yucatán en el Clásico tardío: La Esfera cerámica Canbalam, in González-Crespo, N., GarcíaCook, A. (eds.), Producción alfarera en el México antiguo, México: Instituto Nacional de Antropología e Historia, 345-371. 
Jiménez-Álvarez, S., Belmar, R., Sierra, T., Chung, H., 2006, Estudio tecnológico de la cerámica de pasta fina "Chablekal Temprano e Isla Fina" del sitio costero de Xcambó, Yucatán: Los Investigadores de la Cultura Maya, 14, 502-515.

Jones, L.D., 1986, Lowland Maya pottery: The place of petrological analysis: Oxford, Archaeopress, 115 p.

Jongmans, A.G., van Oort, F., Buurman, P., Jaunet, A.M., 1994, Micromorphology and submicroscopy of isotropic and anisotropic $\mathrm{Al} / \mathrm{Si}$ coatings in a Quaternary Allier terrace, (France), in Ringrose-Voase, A, Humphreys, G.S. (eds.), Soil Micromorphology: Studies in Management and Genesis: Amsterdam, Netherlands, Elsevier, 285-291.

Josephs, R.L., 2005, Short contribution: applying micromorphological terminology to ceramic petrography: Geoarchaeology, 20, 861-865.

Kennett, D.J., Beach, T.P., 2013, Archeological and environmental lessons for the Anthropocene from the Classic Maya collapse: Anthropocene, 4, 88-100.

Krishnan, K., Shah, K., 2005, Beyond wares and shapes: Gaining a Petrographic Perspective on Ancient Indian Pottery, in Biswas, A.K. (ed.), Science in Archaeology and Archaeomaterials: D.K. Printworld, New Delhi, 135-156.

Kubiëna, W.L., 1938, Micropedology: Ames, Collegiate Press, 243 p.

Laviano, R., Muntoni, I.M., 2006, Provenance and technology of Apulian Neolithic pottery, in Maggeti, M., Messiga, B. (eds.), Geomaterials in cultural heritage: London, The Geological Society, 49-62.

Leggo, P.J., Cochemé, J.J., Demant, A., Lee, W.T., 2001, The role of argillic alteration in the zeolitization of volcanic glass: Mineralogical Magazine, 65, 653-663.

López-Varela, S.L., 2014, Ceramics: Maya Pottery, in Selin, H. (ed.), Encyclopedia of the history of science, technology, and medicine in
Non-Western Cultures: Dordrechet, Springer Science Business Media, 1168-1 180.

Loya-González, T., Stanton, T.W., 2014, Late Classic ceramic technology and its social implications at Yaxuná, Yucatán: A petrographical analysis of a sample of Arena Group ceramics, in Stanton, T.W. (ed.), The archaeology of Yucatán: New directions and data: Oxford, Archaeopress, 337-362.

Macphail, R.I., Gourty, M.A., Goldberg, P., 1990, Soil micromorphology in archaeology: Endeavour, 14, 163-171.

Mahmoudi, S., Srasra, E., Zargouni, B., 2008, The use of Tunisian Barremian clay in the traditional ceramic industry: Optimization of ceramic properties: Applied Clay Science, 42, 125-129.

Maritan, L., Mazzoli, C., Michielin, V., Morandi Bonacossi, D., Luciani, M., Molin, G., 2005, The provenance and production technology of Bronze Age and Iron Age pottery from Tell Mishrifeh/Qatna (Syria): Archaeometry, 47, 723-744.

Marshall, R.R., 1961, Devitrification of natural Glass: Geological Society of America Bulletin, 72, 1493-1520.

Merino, E., Banerjee, A., 2008, Terra Rossa genesis, implications for karst, and eolian dust: a geodynamic thread: The Journal of Geology, 116, 62-75.

Milawski, J., 2013, Quaternary volcanic ash transformation in the Maya Lowland: Cincinnati, University of Cincinnati, master in science, thesis, $85 \mathrm{p}$.

Obando, L.G., Jiménez, S., Kussmaul, S., 2011 , Estudio petrográfico de cerámicas mayas, Clásico tardío (600-900 D.C.), Chinikihá, Chiapas, México: Revista Geológica de América Central, 44, 101-1 18.

Obando, L.G., Jiménez, S.P., 2016, Petrografía de la cerámica Nimún y Baca (vajilla Celestún Roja): esfera cerámica Canbalam de la península de Yucatán, México: Revista Geológica de América Central, 54, 85-108. 
Ortega-Gutiérrez, F., Solari, L.A., OrtegaObregón, C., Elías-Herrera, M., MoránIcal, S., Chiquín, M., Keppie, J.D., Torres de León, R., Schaaf, P., 2007, The MayaChortís boundary: a tectonostratigraphic approach: International Geology Review, 449, 996-1024.

Piperno, D.R., 2006, Phytoliths: a comprehensive guide for archaeologists and paleoecologist. Lanham, Altamira Press, 248 p.

Quinn, P.S., Day, P., 2007, Ceramics micropaleontology: the analysis of microfossils in ancient ceramics: Journal of Micropaleontology, 26, 159-168.

Quinn, P.S., 2013, Ceramic petrography. The interpretation of archaeological pottery and related artefacts in thin section: Oxford, Archaeopress, $260 \mathrm{p}$.

Quiñones, H., 1975, Soil study area 4. Intrazonal soils of northern Yucatan Peninsula, in De Pablo, L. (ed.), Guidebook FT-4, International Clay Conference: Mexico, Universidad Nacional Autónoma de México, Institute of Geology, 70-93.

Reedy, G. L., 2008, Thin-section petrography of stone and ceramic cultural materials: London, Archetype Publications, 264 p.

Rice, P.M., 1996, Recent ceramic analysis: 1. Function, style and origins: Journal of Archaeological Research, 4, 133-163.

Rose, W.I., Conway, F.M., Pullinger, C.R., Deino, A., McIntosh, W.C., 1999, An improved age framework for late Quaternary silicic eruptions in northern Central America: Bulletin of Volcanology, 61, 106-120.

Ruddiman, W.F., 2003, The anthropogenic greenhouse era began thousands of years ago: Climatic Change, 61, 261-293.

Ruddiman, W.F., 2007, The early anthropogenic hypothesis: Challenges and responses: Reviews of Geophysics, 45, RG4001, doi:10.1029/2006RG000207.

Sedov, S.N., Solleiro-Rebolledo, E., Gama-Castro, J.E., 2003, Andosol to Luvisol evolution in
Central Mexico: timing, mechanisms and environmental setting: Catena, 54, 495-513.

Sedov, S., Solleiro-Rebolledo, E., Fedick S.L., Pi-Puig, T., Vallejo-Gómez, E., FloresDelgadillo, M., 2008, Micromorphology of a soil catena in Yucatan: Pedogenesis and geomorphological processes in a tropical karst landscape, in Kapur, S. (ed.), New trends in soil micromorphology: Berlin Heidelbarg, Springer-Verlag, 19-37.

Sedov, S., Stoops, G., Shoba, S., 2010, Chapter 13. Regoliths and soils on volcanic ash, in Stoops, G., Marcelino, V., Mees, F. (eds.), Interpretation of micromorphological features of soils and regoliths: The Netherlands, Elsevier, 275-303.

Servicio Geológico Mexicano, 2007, Carta geológica de la República Mexicana, 1:2000000: Pachuca, Hidalgo, México, Secretaria de Economía, 1 mapa.

Shepard, A.O., 1937, Ceramic Technology: Carnegie Institution of Washington, Year Book, 36, 144-145.

Shepard, A.O., 1964, Ceramic development of the Lowland and Highland Maya (abstract), in Actas y Memorias del XXXV Congreso Internacional de Americanistas Vol.1: Mexico City, Mexico (1962), Instituto Nacional de Antropología e Historia, 518-520.

Shepard, A.O., 1968, Ceramics for the archaeologist $\left(5^{\text {th }}\right.$ edition): Washington, DC: Carnegie Institution of Washington Publication 609, 414 p.

Sierra-Sosa, T.N., 2004, Relaciones culturales y mercantiles entre el puerto de Xcambó de la costa norte de Yucatán y el litoral veracruzano-tabasqueño-campechano: Estudios Mesoamericanos, 6, 13-19.

Simms, S.R., Berna, F., Bey, G.J., 2013, A prehispanic Maya pit oven? Microanalysis of fired clay balls from the Puuc región, Yucatan, Mexico: Journal of Archaeological Science, 40, 1144-1157. 
Smith, R.E., Willey, G.R., Gifford, J.C., 1960, The type-variety concept as a basis for the analysis of Maya pottery: American Antiquity, 30, 330-340.

Solís-Castillo, B., Solleiro-Rebolledo, E., Sedov, S., Liendo, R., Ortiz-Pérez, M., LópezRivera., S., 2013, Paleoenvironment and human occupation in the Maya Lowlands of the Usumacinta River, Southern Mexico: Geoarchaeology, 28, 268-288.

Solís-Castillo, B., Golyeva, A., Sedov, S., SolleiroRebolledo, E., López-Rivera, S., 2015, Phytoliths, stable carbon isotopes and micromorphology of a buried alluvial soil in Southern Mexico: A polychronous record of environmental change during Middle Holocene: Quaternary International, 365, 150-158.

Solleiro-Rebolledo, E., Cabadas-Báez, H.V., Pi, P.T., González, A., Fedick, S. L., Chmilar, J. A., Leonard, D., 2011, Genesis of hydromorphic Calcisols in wetlands of the northeast Yucatan Peninsula, Mexico: Geomorphology, 135, 322-331.

Solleiro-Rebolledo, E., Sedov, S., Macías, J.L., Pi, P.T., 2007, Late Holocene paleopedological records contained in tephra from El Chichon volcano, Chiapas, Mexico: Catena, 71, 444-455.

Solleiro-Rebolledo,E., Terhorst, B., Cabadas-Báez, H., Sedov, S., Damm, B., 2015, Influence Mayan land use on soils and pedosediments in karstic depressions in Yucatan, Mexico, in Lucke, B., R. Bäumler, Schmidt, M. (eds.), Soils and Sediments as archives of environmental change. Geoarchaeology and Landscape in the Subtropics and Tropics: Erlanger Geographische Arbeiten Band 42, 233-266.

Stoops, G., 2003, Guidelines for analysis and description of soil and regolith thin sections: Madison, Soil Science Society of America, $184 \mathrm{p}$.
Tankersley, K.B., Scarborough, V.L., Dunning, N., Huff, W., Maynard, B., Gerke, T.L., 2011, Evidence for volcanic ash fall in the Maya lowlands from a reservoir at Tikal, Guatemala: Journal of Archaeological Science, 38, 2925-2938.

Targulian, V.O., Goryachkin, S.V., 2004, Soil memory: types of record, carriers, hierarchy and diversity: Revista Mexicana de Ciencias Geológicas, 21, 1-8.

Tschegg, C., 2009, Post-depositional surface whitening of ceramic artifacts: alteration mechanisms and consequences: Journal of Archaeological Science, 36, 2155-2161.

Tucker, M.E., 2012, Sedimentary petrology: an introduction to the origin of sedimentary rocks ( $3^{\text {th }}$ edition): India, Wiley, $272 \mathrm{p}$.

Twiss, P.C., 1992, Predicted world distribution of C3 and C4 grass phytoliths, in Rapp, Mullholland, S.C. (eds.), Phytolith systematics emerging issues. Advances in Archaeology and Museum Science 1: New York, Plenum Press, 113-128.

van Doosselaere, B., Delhon, C., Hayes, E., 2014, Looking throught voids: a microanalysis of organic- derived porosity and bioclasts in archaeological ceramics from Koumbi Saleh (Mauritania, fifth/sixth-seventeenth century $\mathrm{AD})$ : Archaeological and Anthropological Sciences, 6, 373-396.

Vaughan, S.J., 1995, Ceramic petrology and petrography in the Aegean: American Journal of Archaeology, 99, 115-117.

Velde, B., Druc, I.C., 1999, Archaeological ceramic materials: Berlin Heidelberg, Springer-Verlag, 299 p.

Villaseñor, I., Graham, E., 2010, The use of volcanic materials for the manufacture of pozzolanic plasters in the Maya lowlands: a preliminary report: Journal of Archaeological Science, 37, 1339-1347.

Walkington, H., 2010, Soil science applications in archaeological contexts: A review of key challenges: Earth-Science Reviews, 103, 122-134. 
Wallis, N.K., Cordell, A.S., Newsrom, L.A., 2011, Using hearths for temper: petrographic analysis of Middle Woodland charcoaltempered pottery in Northeast Florida: Journal of Archaeological Science, 38, 2914-2924.

Ward, W.C., 1985, Part II Quaternary geology of northeastern Yucatan Peninsula, in Ward, W.C., Weidie, A.E., Black, E. (eds.), Geology and hydrogeology of the Yucatan and Quaternary Geology of Northastern Yucatan Peninsula: New Orleans, U.S.A., New Orleans Geological Society, 22-95.

Whitbread, I.K., 1986, The characterisation of argillaceous inclusions in ceramic thin sections: Archaeometry, 28, 79-88.

Whitbread,I.K., 1989, A proposalfor the systematic description of thin sections towards the study of ancient ceramic technology, in Maniatis, Y. (ed.), Archaeometry: Proceedings of the $25^{\text {th }}$ International Symposium: Amsterdam, Elsevier, 127-138.

Whitbread, I.K., 1995, Greek transport amphorae: A petrological and archaeological study. Athens: British School at Athens, 453 p.

Whitbread, I.K., 2017, Fabric description of archaeological ceramics, in Hunt, A.M.W. (ed.), The Oxford handbook of archaeological ceramic: New York, USA, Oxford University Press, 200-216.

Wieder, M., Adan-Bayewitz, D., 2002, Soil parent materials and the pottery of Roman Galilee: a comparative study: Geoarchaeology, 17, 393-415.

Williams, M., Zalasiewicz, J.A., Waters, C.N., Landing, E., 2014, Is the fossil record of complex animal behavior a stratigraphical analogue for the Anthropocene?, in Waters C.N., Zalasiewicz, J., Williams, M., Ellis, M.A., Snelling, A.M. (eds.), A stratigraphical basis for the Anthropocene, Geological Society Special publication 395: London, The Geological Society, 143-148.
Williams, M., Zalasiewicz, J., Waters, C.N., Edgeworth, M., Bennett, C., Barnosky, A.D., Ellis, E.C., Ellis, M.A., Cearreta, A., Haff, P.K., Ivar do Sul, J.A., Leinfelder, R., McNeill, J.R., Odada, E., Oreskes, N., Revkin, A., Richter, D., Steffen, W., Summerhayes, G., Syvitski, J., Vidas, D., Wagreich, M., Wing, S.L., Wolfe, A.P., Zhisheng, A., 2016, The Anthropocene: a conspicuous stratigraphical signal of anthropogenic changes in production and consumption across the biosphere: Earth's Future, 4, 34-53.

Wilson, E.M., 1980, Physical geography of the Yucatan peninsula, in Moseley, E.H., Terry, E.D. (eds.), Yucatan, A World Apart: Birmingham, U.S.A., University of Alabama Press, 5-40.

Zalasiewicz, J., Williams, M., Smith, A.G., Barry, T.L., Coe, A. L., Bown, P.R., Brenchley, P., Cantrill, D., Gale, A., Gibbard, P., Gregory, F.J., Hounslow, M.W., Kerr, A.C., Pearson, P., Knox, R., Powell, J., Waters, C., Marshall, J., Oates, M., Rawson, P., Stone, P., 2008, Are we now living in the Anthropocene?: GSA Today, 18, 4-8.

Zalasiewicz, J., Williams, M., Waters, G.N., Barnosky, A.D., Haff, P., 2014a, The technofossil record of humans: The Anthropocene review, 1, 34-43.

Zalasiewicz, J., Kryza, R., Williams, M., 2014b, Can the Anthropocene Series be defined and recognized?, in Waters, C.N., Zalasiewicz, J., Williams, M., Ellis, M.A., Snelling, A.M. (eds.), A stratigraphical basis for the Anthropocene, Geological Society Special publication 395: London, The Geological Society, 39-54. 